\title{
Artelogie
}

Recherche sur les arts, le patrimoine et la littérature de l'Amérique latine

$3 \mid 2012$

Image de la nation : art et nature au Chili

\section{Paisaje y nación: la majestuosa montaña en el imaginario del siglo XIX}

\section{Paulina Ahumada F.}

\section{OpenEdition}

\section{Journals}

Edición electrónica

URL: https://journals.openedition.org/artelogie/6841

DOI: 10.4000/artelogie.6841

ISSN: 2115-6395

\section{Editor}

Association ESCAL

Referencia electrónica

Paulina Ahumada F., «Paisaje y nación: la majestuosa montaña en el imaginario del siglo XIX», Artelogie [En línea], 3 | 2012, Publicado el 12 septiembre 2012, consultado el 07 enero 2022. URL: http://journals.openedition.org/artelogie/6841 ; DOI: https://doi.org/10.4000/artelogie.6841

Este documento fue generado automáticamente el 7 enero 2022.

Association ESCAL 


\title{
Paisaje y nación: la majestuosa montaña en el imaginario del siglo XIX
}

\author{
Paulina Ahumada F.
}

1 Es recurrente presentar la Cordillera de los Andes como uno de los paisajes más característicos de la nación chilena, una muralla natural que convierte al país en una isla entre la cordillera y el mar. Pareciera con esto que se asume geografía y paisaje como términos sinónimos. En este artículo, se propone reflexionar sobre esto usando dos lentes: por una parte las teorías del paisaje como construcción cultural, que postulan que el paisaje no es simplemente una realidad material o natural, sino un artificio, que ensambla naturaleza y cultura (Anderman, 2008; Berque, 1994; Besse, 2009; Simmel, 1912; Wyle, 2007) y, por otra, la idea de la nación como una comunidad imaginada, una entidad que aunque subjetivamente parece antigua, es históricamente moderna (Anderson, 2000).

2 Se propone investigar en particular cómo se construye el paisaje de la cordillera como un símbolo de la nación durante el siglo XIX. Un proceso que no es aislado, sino que se da también en otros los países americanos: en Argentina será la pampa o en Brasil la selva lo que se convierta en paisaje nacional.

3 Preguntarse por cómo se construye un paisaje de la nación será en este caso preguntarse por cómo este se representa, por lo tanto, la pregunta que guía el artículo será ¿Cómo se representa la cordillera durante el siglo XIX, en el contexto de la formación de la nación?

4 La hipótesis que se propone demostrar es que existe una representación de la cordillera como un paisaje nacional, la cual se emprende desde el Estado, como parte de las políticas de formación de un Estado fuerte y centralizado (Mizón, 2001) que se construye desde la ciudad de Santiago como capital y en donde la montaña sirve como un motivo de unidad. Este tema forma parte de los estudios sobre las relaciones entre paisaje, mirada y poder, campo ubicado en el cruce entre los estudios de la poscolonialidad, la geografía cultural y los estudios culturales y visuales, que en forma crítica cuestionan la 
neutralidad de la geografía postulando que esta se construye desde la mirada y los espacios de poder. En el libro Modos de ver (1972), John Berger estudia la construcción histórica de la mirada, constatando que el paisaje emerge de la mirada moderna, con la pintura de paisaje del Renacimiento. Mary Louis Pratt (1992) y W. J. T. Mitchell (1994), en tanto, observan su origen a través de los relatos de los artistas y científicos viajeros europeos de los siglos XVIII y XIX y estudian la mirada que desde la metrópolis se construyó de las colonias. Es esta mirada imperial la se reproducirá después en el relato de las nuevas naciones. De ahí surgen los grandes espacios americanos, la "naturaleza virgen", exuberante y poderosa, vista con los ojos románticos del siglo XIX.

De este campo emergen otras cuestiones que están en el trasfondo del problema: de acuerdo a lo postulado por los estudios de la poscolonialidad (BEVERLY, 1995; QUIJANO, 2001), entendemos la nación como un constructo, obra de una elite criolla que remplaza en el siglo XIX a las elites coloniales. En tanto grupo hegemónico, dicha elite continúa el orden colonial, invisibilizando y marginando del proceso a los otros grupos sociales (indios, mestizos, pobres...). Ante esto, surge entonces una pregunta derivada: ¿Esta cordillera que se erige como imagen oficial estaría ocultando otras cordilleras u otras representaciones de esta?

6 A su vez, entre las teorías del paisaje, es reconocida la tensión que existe entre el paisaje como representación (como mirada) y el paisaje como experiencia (el hacer) (BESSE, 2009; WYLE, 2007). Esto lleva justamente a cuestionarse si es suficiente indagar el paisaje solo a través de la visualidad. Encontrar otras representaciones exige, al parecer, traspasar el campo de lo visual y preguntarse por la experiencia del espacio. Esto es lo que se ha estudiado desde la fenomenología del espacio, el ver y el hacer, como parte de un relato que construye el espacio (De Certeau, 1996).

7 A partir de estas preguntas y supuestos, se analizará a continuación una selección de imágenes y textos, así como también libros ilustrados, soporte característico, por lo demás, del siglo XIX. Tanto estos libros como las imágenes y textos fueron producidos o están relacionados al Estado y en general han tenido una amplia difusión. El corpus a analizar se conforma por el Atlas de la Historia Física y Política de Chile de Claudio Gay (1854), el Atlas de la Geografía Física de la República de Chile de Amado Pissis (1875), dos pinturas de Juan Mauricio Rugendas (1834 y 1843), el libro Chile Ilustrado de Recaredo Tornero (1872) y la pintura de Pedro Lira La fundación de Santiago (1889). En nuestro análisis, los objetos que conforman este conjunto dialogan entre sí y producen una secuencia que recorre el siglo XIX.

Para indagar en las imágenes, nos valemos, en forma discreta, de la distinción de tres niveles de percepción que propone Panofsky, según expone y critica Burke (BURKE, 2005: 45-52). Según este método, se distingue en primer lugar aquello que se ve (cerros, gente, animales, ubicados de tal forma...); en segundo lugar, el significado explícito o convencional (vista de Santiago...); y en tercer lugar la interpretación, que se refiere a lo que se quiere decir en forma intrínseca, atendiendo tanto a lo señalado por el propio autor como al uso que posteriormente se haga de la imagen. Este último paso supone indagar en sus contextos de producción y difusión.

El trabajo se ordenará en tres partes, usando el modelo del Atlas de Gay para mostrar el territorio, seguido en cierta forma por Pissis y Tornero: un itinerario que va del mapa a la vista y luego, a los tipos y costumbres. 


\section{La obra de Gay como un hito dentro de la formación de la nación} casi cuarenta años, es reconocida y ha sido ampliamente estudiada como una pieza fundacional de la cultura de la nación ${ }^{1}$ (MIZON, 2001; SAGREDO, 2009, 2004), y es por esto que se utilizará como entrada e hilo conductor del trabajo. en el Colegio de Santiago dirigido en ese entonces por el intelectual venezolano Andrés Bello. Pero dos años después firmó un nuevo contrato con el gobierno, con Diego Portales como Ministro de Interior, para desarrollar un estudio científico de la nación. Según el contrato original, Gay debía realizar la obra en cuatro años, pero finalmente recorrió el país durante doce años y demoró veinticinco más en editarla y publicarla en Europa. El primer tomo de la Historia Física y Política de Chile fue publicado en París en 1844, con 130 páginas que abordaban los inicios de la conquista y con cinco láminas. La obra fue una publicación por entregas que concluyó en 1871 (SAGREDO, 2004: 30).

Gay, como Humboldt y los naturalistas del siglo XVIII y XIX fue un científico-dibujante. El dibujo juega un rol central como herramienta para conocer, inventariar y difundir la América postcolonial. Por esto, dentro de la obra hay dos tomos que reúnen las ilustraciones que complementan el resto de los volúmenes: el Atlas de la Historia Física y Política de Chile (1854). Según cuenta Gay en su correspondencia, editar el Atlas fue una tarea dificilísima. Durante más de diez años debió reunirse y trabajar con un gran número de personas, "vigilar más de cincuenta personas ocupadas en los dibujos, en el grabado y en el colorido de las láminas" (ídem: 32), revisar pruebas de imprenta, elegir papeles y enfrentar el problema de los elevados costos de publicación. Dos años después de su regreso a Francia había publicado con el primer tomo cinco láminas que envió rápidamente a sus "suscriptores" (el gobierno de Chile y particulares), pero faltaban aun diez años para que saliera efectivamente el Atlas. Los dos tomos contienen 315 láminas: la primera de ellas corresponde al retrato de Portales, luego hay 21 mapas, 55 representaciones de antigüedades chilenas, imágenes de los araucanos, vistas de ciudades, paisajes, costumbres, etc. y, finalmente, 238 láminas botánicas y zoológicas. En el primer tomo se distingue el orden ya señalado: mapas, vistas y tipos y costumbres.

\section{El mapa y la construcción de la frontera natural}

En su libro Comunidades imaginadas, el teórico cultural Benedict Anderson plantea que la comunidad imaginada que conforma a la nación se supone a sí misma como una entidad limitada, con fronteras finitas aunque elásticas, fuera de las cuales hay otras naciones. En su proceso de construcción, la cartografía funciona como una herramienta clave, que no refleja la realidad sino que la imagina, actúa como un modelo que la prefigura (Anderson, 2000). Desde el ámbito de los relatos cotidianos del espacio, Michel de Certeau señala al deslinde como lo que estructura el espacio. Sostiene que hay dos formas coexistentes de relatar el espacio: como itinerario ("fui de tal lugar a tal lugar") y como mapa ("al lado del comedor está la cocina"). El primero relata la experiencia, el hacer; el segundo, el ver. Los mapas medievales relataban el itinerario, luego, los mapas modernos buscaron convertirse en una herramienta totalizadora que contuviera todo 
el saber geográfico sobre ese lugar. En ambos casos, según este autor, establecer deslindes es lo fundamental: "toda la espacialidad habla de la determinación de fronteras". Delimitar significa fijar fronteras, pero al mismo tiempo dar con las formas para traspasarlas: la frontera y el puente son entonces las figuras centrales para hablar de espacio (de Certeau, 1996: 135). Estas ideas sobre el proceso de delimitar y el rol que juegan en ello el hacer y el ver, serán las herramientas que usaremos para indagar en la representación de la cordillera en la primera cartografía del Chile republicano, realizada por Gay y Pissis.

Cuando el gobierno de Chile encarga su trabajo a Gay, estaba reaccionando a la necesidad inmediata de contar con un mapa del territorio que la joven república debía administrar desde Santiago. A esa fecha, observa Gay, los mapas existentes eran deficientes e inexactos. Y -hay que agregar- no representaban el territorio de la República de Chile sino el de la Capitanía General o de una porción de Sudamérica. Durante la colonia, el dominio del espacio se había hecho desde el mar y desde las costas, pero con las independencias lo que se necesita dominar y por lo tanto registra era el interior, que es lo que hace Gay metódicamente en sus expediciones a las distintas provincias entre 1830 y 1841.

La primera lámina del Atlas es el Mapa de la Inteligencia de la Historia Física y Política de Chile, una lámina plegada de gran formato que comprende todo el territorio de Chile, entre los paralelos 25 (Desierto de Atacama) y 44 (Archipiélago de las Islas Guaytecas). Mientras los límites norte y sur resultan indefinidos (el mapa simplemente se corta en el paralelo correspondiente), el oriente y poniente están claramente demarcados por la cordillera y el mar. En la versión facsímil de 2004 (Fig. 1), el territorio propio está coloreado, diferenciándose así del territorio de la República Argentina. La graficación hace resaltar a lo largo de todo el mapa, siguiendo los Andes, un cordón blanco que hace las veces de la frontera natural. Contrario a esta naturalización del límite hay que recordar que hasta 1778, cuando se crea el Virreinato de La Plata, el Reino de Chile comprendía la provincia de Cuyo, continuando con la organización del espacio precolombino: para los Incas, los Andes no eran la frontera sino al revés, la columna vertebral del imperio, el que se recorría a través de la red de caminos del Inca que iban de norte a sur por las dos vertientes de los Andes, unidos por caminos que cruzaban las montañas (Ahumada, 2003).

En el mapa de Gay están trazados el Camino Real (en amarillo) y el itinerario del autor (en rojo), con el que se da cuenta expresamente que el naturalista recorrió los interiores cordilleranos de Coquimbo, La Serena-Ovalle, Illapel, Santiago, Colchagua, Concepción y Valdivia. Esto corresponde justamente a los mapas de las provincias que presenta a continuación tal como se había comprometido en su contrato. Es interesante comparar los acentos y diferencias con que se representan los Andes en el mapa general y en las respectivas cartografías regionales: resalta, en primer lugar, que varias de estas cartas provinciales disponen el espacio en sentido transversal, siguiendo el curso de los ríos entre la desembocadura y su nacimiento en la cordillera. Según Sagredo el orden transversal corresponde al sentido de ocupación colonial, donde el acceso a las regiones estaba dado desde el puerto, para seguir luego el curso del valle, bordeando el río (Sagredo, 2009). Este mismo orden transversal, con el mar abajo y la cordillera arriba, es el del "mapamundi" de Guamán Poma (1615) o el del Reyno de Chile de Alonso de Ovalle (1646). En el Atlas de Gay el nuevo orden norte-sur es todavía precario. Responde más al proyecto de dar unidad a la nación afirmándose en la 
continuidad de la cordillera y el mar, que a la realidad, dada por la proyección de un camino central norte-sur.

Fig. 1. Detalle C. Gay, “Mapa de la Inteligencia de la Historia Fisica Politica de Chile”, 1854

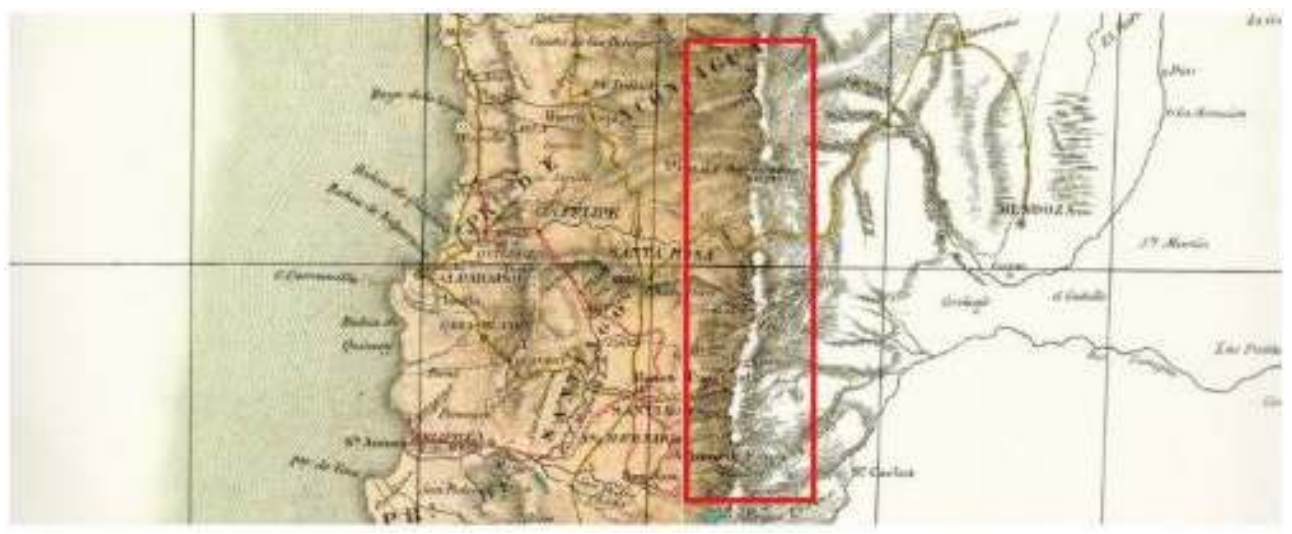

Fig. 2. Detalle C. Gay., “Provincias de Santiago y Valparaiso, 1854

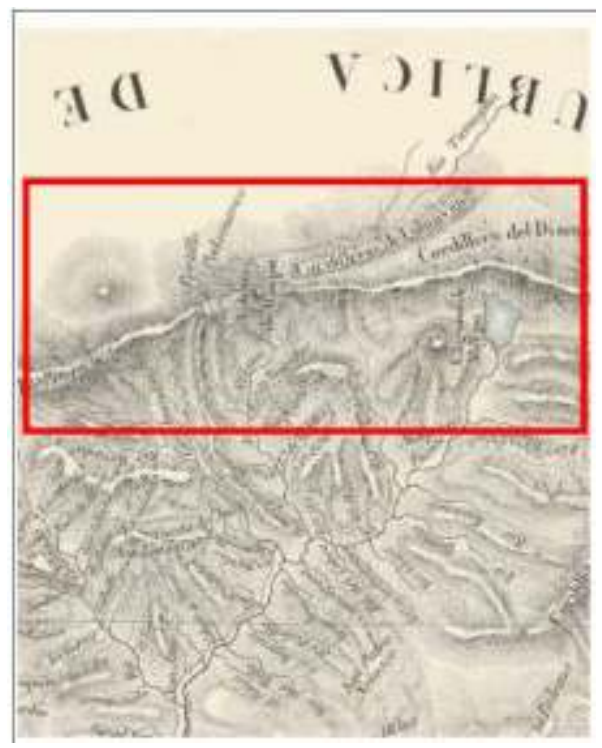


Fig. 3. Detalle C. Gay, “Provincia Cauquenes”, 1854

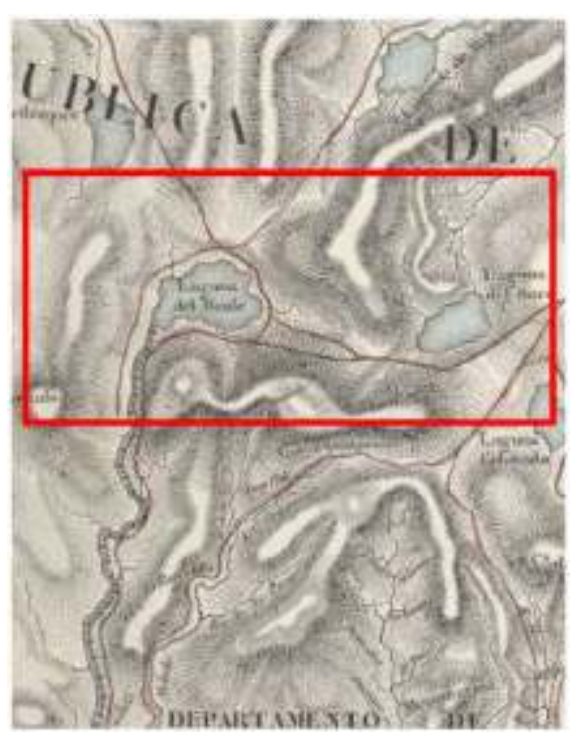

Los mapas provinciales presentan, por su escala, un gran nivel de detalle. En los casos de Santiago y Cauquenes (Fig. 2 y 3), están dibujadas y nombradas en detalle distintas cadenas de montañas que forman los Andes. En la simbología, muy breve, se señalan las capitales de departamento, los límites entre provincias y departamentos y solo dos trazos más: el Camino Real, que corre más menos discontinuo de norte a sur y los Caminos para pasar las cordilleras. Esto último refleja la relevancia y la práctica frecuente de cruzar la montaña. Al hablar de "cordilleras" en plural, nombrar cada río y las cadenas de montañas, se muestra la experiencia de una cordillera que se recorre a lomo de mula, y no de aquella que es vista desde lejos. Pero mientras en el mapa de la Provincia de Santiago (Fig. 2), se vuelve a usar la gráfica más menos definida del cordón blanco, como frontera natural, en el interior de Cauquenes (Fig.3), el cordón desaparece. Aparecen cordones disgregados y varios caminos para pasar las cordilleras (en rojo), que rodean la laguna del Maule, y pasan a uno y otro lado de una frontera invisible. La diferencia está dada solo por el rótulo "República de La Plata".

18 A la cartografía de Gay le sigue la del geólogo francés Amado Pissis, que también responde a un encargo del gobierno. En 1842, cuando Gay regresó a Francia había dejado una copia de su mapa de Chile al ministro Montt, que según señaló el propio autor "es bastante exacta y más que suficiente para cualquier operación administrativa" (SAGREDO, 2004: 29). Pero a la espera la versión definitiva, que demoró más de una década, el gobierno encargó en 1849 a Pissis levantar un plano topográfico y geológico del país como parte de un plan de definición de la geografía física de Chile. Pissis, como Gay, va a "recorrer paso a paso la alta cordillera de los Andes y reunir numerosos datos sobre la Orografía, la Geología, la Meteorología y la distribución de los seres orgánicos de una de las regiones más notables de América del Sur" (Pissis, 1875: V). Sus estudios se basan, según sus propias palabras, en las obras de los naturalistas, en particular "el grande trabajo del señor Claudio Gay" y las publicaciones sobre mineralogía del científico polaco afincado en Chile, Ignacio Domeyko². A diferencia del naturalista Gay, Pissis tenía una formación más específica, en geología y por lo mismo, su mapa debía profundizar el proceso de un levantamiento científico del territorio. Pissis, como Humboldt, había estudiado en la Escuela de Minas, por lo que concentró su atención en las formaciones geológicas y los recursos mineros, justamente uno de los 
objetivos del Estado al contratarlo: recabar conocimiento y difundir la existencia de riquezas mineras para ser explotadas con capitales y tecnología europeos (González, 2007).

19 La obra de Pissis se publicó recién en 1875, compuesta de los mapas, la Geografía física y un Atlas. El Atlas se inicia con una Carta Orográfica y con un conjunto de cinco láminas que representan el "Perfil de las Cordilleras de Chile. Desde el grado 24 al 42". (Figs. 4 y 5). Después vienen las vistas que, a diferencia de las de Gay, presentan formaciones rocosas de las altas cumbres y volcanes, todas vacías y deshabitadas. Siguiendo los registros de Humboldt, incluye una lámina con el "Límite Inferior de las Nieves Perpetuas", en la que se destaca la zona central, con las cumbres más altas y con una mayor margen de nevadas perpetuas. Los Perfiles mismos representan las cordilleras vistas como planos verticales, donde se nombran las altas cumbres (el Monte Aconcagua, el Tupungato, Cerro El Plomo...) y los pasos (Boquete de Uspallata, Portillo de los Piuquenes...). Del conjunto de los perfiles que muestran todo lo largo del territorio, la zona central es una figura donde las alturas medias bordean los $5000 \mathrm{msnm}$. En contraste, cerca de Concepción las cumbres solo llegan a los $2000 \mathrm{msnm}$.

Figs. 4 y 5 . Detalles de “Perfil de las Cordilleras de Chile", 1875, grabado, en A. Pissis

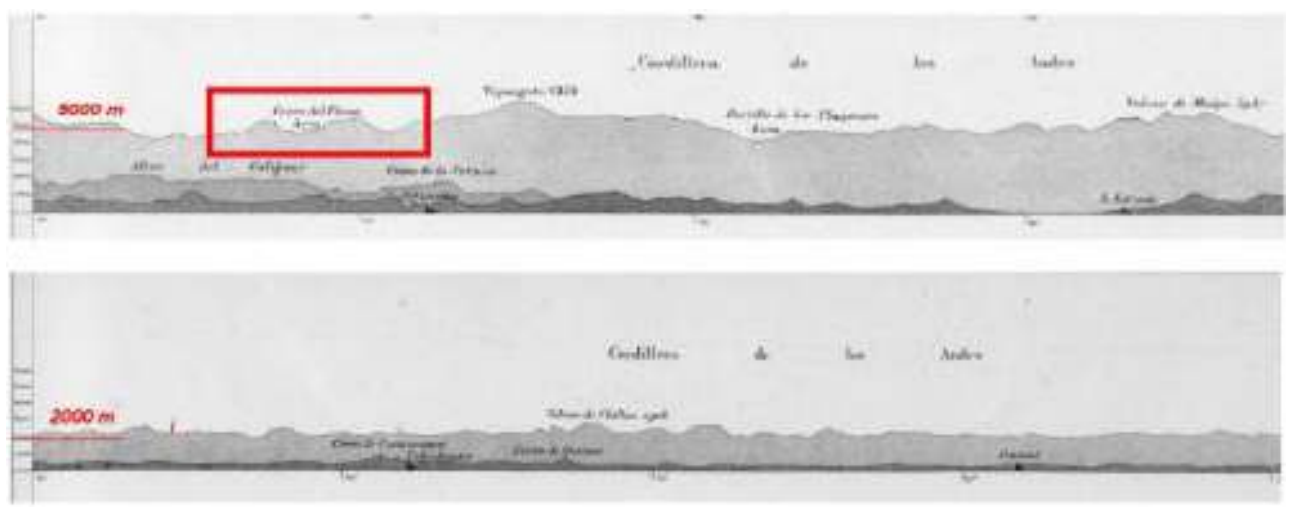

Atlas de la geográfica física de la República de Chile

Los Andes que representa Pissis, en la zona de Santiago y Valparaíso, aparecen así como un muro inmenso, la expresión que usó Darwin (1834) al describir la montaña vista desde Santiago y que se repetirá luego durante el siglo XX (la "muralla de granito" de Benjamín Subercaseaux en Chile o una loca geografía de 1940). En los mapas de Gay y los perfiles de Pissis, se distingue la intencionalidad de mostrar en forma clara y distintiva la cordillera, ya sea como un cordón blanco o como un muro, que sirve para fijar la frontera, aun cuando en el detalle los múltiples cordones muestren lo difícil que es establecer ese deslinde abstracto. Esta construcción es un ejercicio visual, pero que no está separado de la práctica del espacio. Siguiendo a Michel De Certeau, se pude decir que existe un hacer que permite un ver, lo que articula la cultura "ordinaria" (del hacer) al discurso científico (del ver). A pesar de su intención de cientificidad (de un mapa objetivo y totalizador) el mapa de Gay mantiene la idea premoderna de representar su propio recorrido y grafica el trazo del "Itinerario del autor" y los "Caminos para pasar las cordilleras". A su vez, los perfiles de Pissis destacan tanto las cumbres como los boquetes y portillos, que corresponden a las puertas o puentes, que son la posibilidad 
("hay una puerta") de traspasar el límite o de cerrarlo. El puente, como la puerta, es ambiguo: unas veces suelda y otras supone insularidad (de Certeau, 1996: 132-140).

La delimitación coincide en la zona central con cumbres especialmente altas, de nieves perpetuas y visibles desde las principales ciudades, algo que claramente no sucede en las zonas sur y norte. En este sentido, el imaginario de la frontera natural, aquella majestuosa y blanca montaña cantada en el Himno nacional (1847), se hace desde Santiago, capital del país y sede de gobierno. Debido a guerras y negociaciones con los países vecinos a lo largo del siglo XIX, las fronteras del norte y sur varían notablemente, pero por sobre los cambios, se mantiene la unidad imaginada dada por las delimitaciones inamovibles de la zona central: un valle entre la cordillera y el mar.

\section{Esa blanca estela como escenario de la historia nacional}

Así como los mapas y perfiles forman un conjunto que da cuenta de la construcción de la frontera, las vistas forman otro conjunto, que está entrelazado al primero, como sucede en aquellos planos antiguos en que se presentaba la planta y el alzado de una ciudad en una misma imagen, y que luego, con el desarrollo de la cartografía moderna pasaron a representarse por separado.

Entre las vista interesa indagar la notable secuencia que se abre con la lámina "Vista del Valle del Mapocho. Sacada del Cerro de Santa Lucía” del Atlas de Gay (1854) y que va hasta la pintura La fundación de Santiago de Pedro Lira (1889), pasando por las ilustraciones del Chile Ilustrado de Recaredo Tornero de 1872 (Figs. 6, 7, 8 y 9), y que como conjunto entrelazan el territorio y la historia.

En esta secuencia se reproduce un mismo punto de vista desde el cerro Santa Lucía mirando hacia el oriente. En el primer plano, al costado derecho se observa una roca característica, luego en el plano medio se muestra el valle fértil del río Mapocho y al fondo la "Cordillera de El Plomo", como la llama Gay en su carta provincial, formada por los cerros El Plomo, El Altar y La Paloma. La silueta de estos tres cerros es la que se distingue en el perfil de Pissis (detalle Fig. 4). Si bien El Tupungato y el Volcán San José son las cumbres más altas en la latitud de Santiago, estas no son visibles desde la ciudad, por lo que la imagen que se reproduce a lo largo del siglo XIX como fondo de la ciudad capital y escenario de la historia patria, es aquella que muestra las cumbres de El Plomo.

Esta secuencia de imágenes representa a Santiago, pero más allá de eso, se puede decir que forma parte de un discurso oficial, en la medida en que cada una de ellas es objeto de encargo, difusión o adquisición del Estado chileno. Al igual que en el mapa y en la construcción de la frontera, aquí se despliega una historia nacional construida desde Santiago.

La litografía que inaugura la secuencia, Vista del Valle del Mapocho (F. Lehnert d'après Rugendas et Gay) (Fig. 6) es una de las tres vistas de Santiago que contiene el Atlas de Gay, donde la constante es el mismo telón de fondo de los cerros de El Plomo. En las tres está la mano del dibujante y pintor alemán Juan Mauricio Rugendas, que además repite este fondo en otras dos pinturas (Figs. 7 y 11). La repetición de las montañas en el caso de las litografías puede responder a la forma de producción de los grabados que, como relata Gay, se lleva a cabo por una gran cantidad de dibujantes y grabadores que 
combinan fondos, escenas y figuras. Pero lo significativo es que en este proceso se dan varias elecciones: Gay elige las imágenes de Rugendas y Rugendas opta reiteradamente por esas cumbres, lo que supone mostrar un saber geográfico que ya estaba en el mapa (a primera vista se ven más altas las cumbres del San Ramón que están más próximas).

Fig. 6. J.M. Rugendas "Vista del Valle del Mapocho

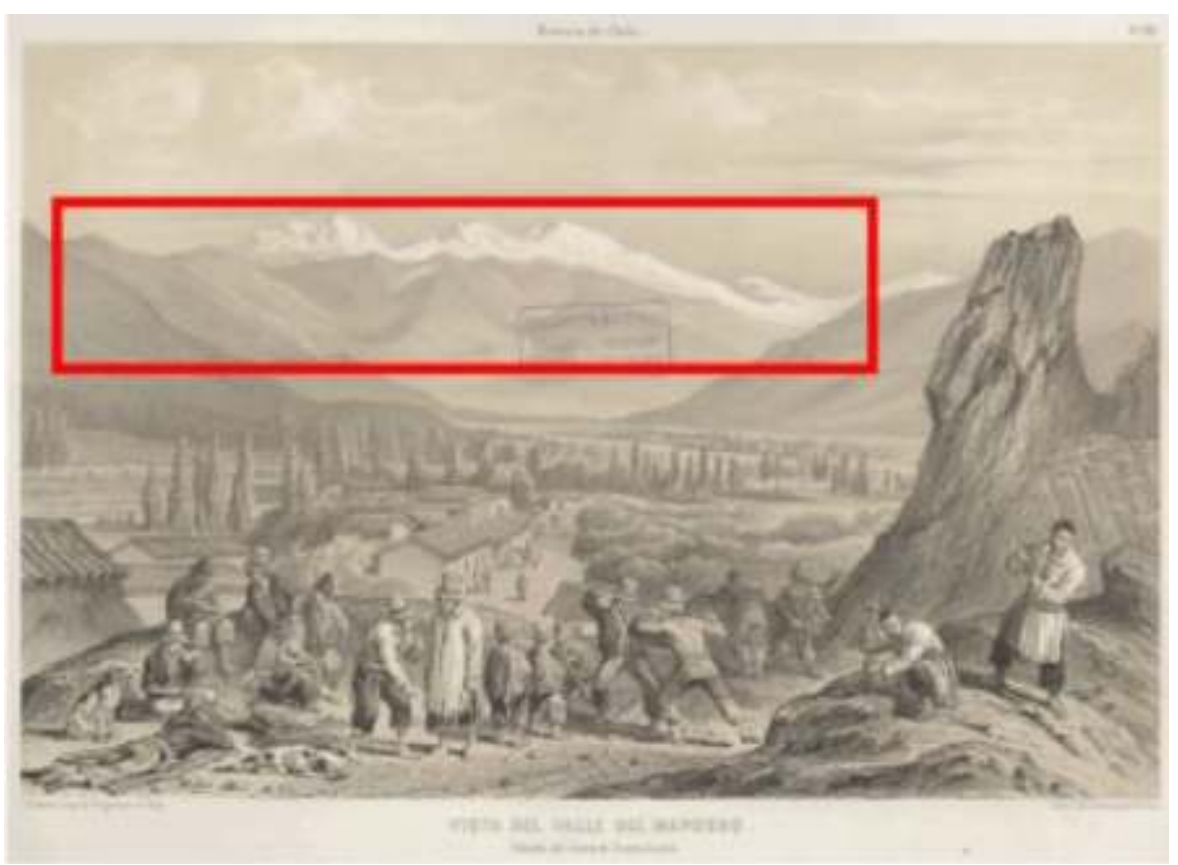

Sacada del Cerro de Santa Lucia", 1854, litografía, en C. Gay, Atlas de la historia física y política de Chile

Fig. 7. J.M. Rugendas, “Recuerdo de Santiago” 1843

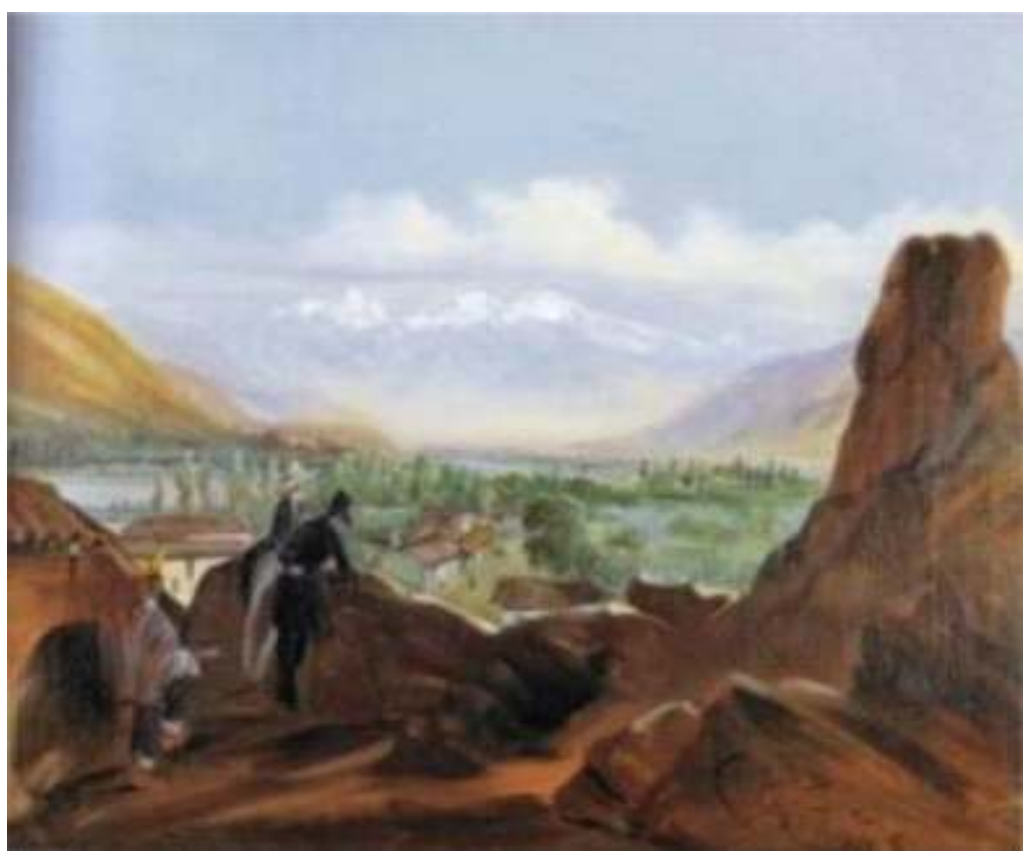

Óleo sobre tela, 35 × $45 \mathrm{~cm}$

Colección particular 
Fig. 8. "Santiago. Vista general tomada del cerro de Santa Lucia", 1872 en R. Tornero, Chile Ilustrado

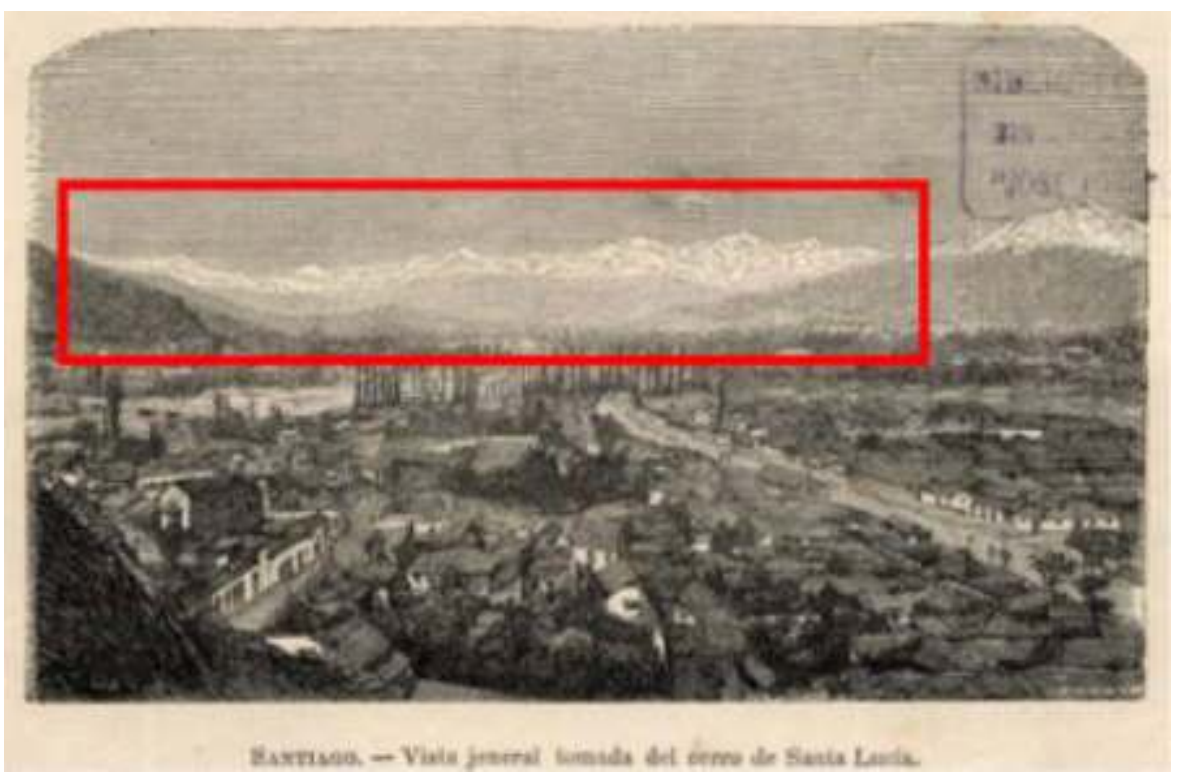

Fig. 9. P. Lira. “La Fundación de Santiago por Pedro de Valdivia”, 1889

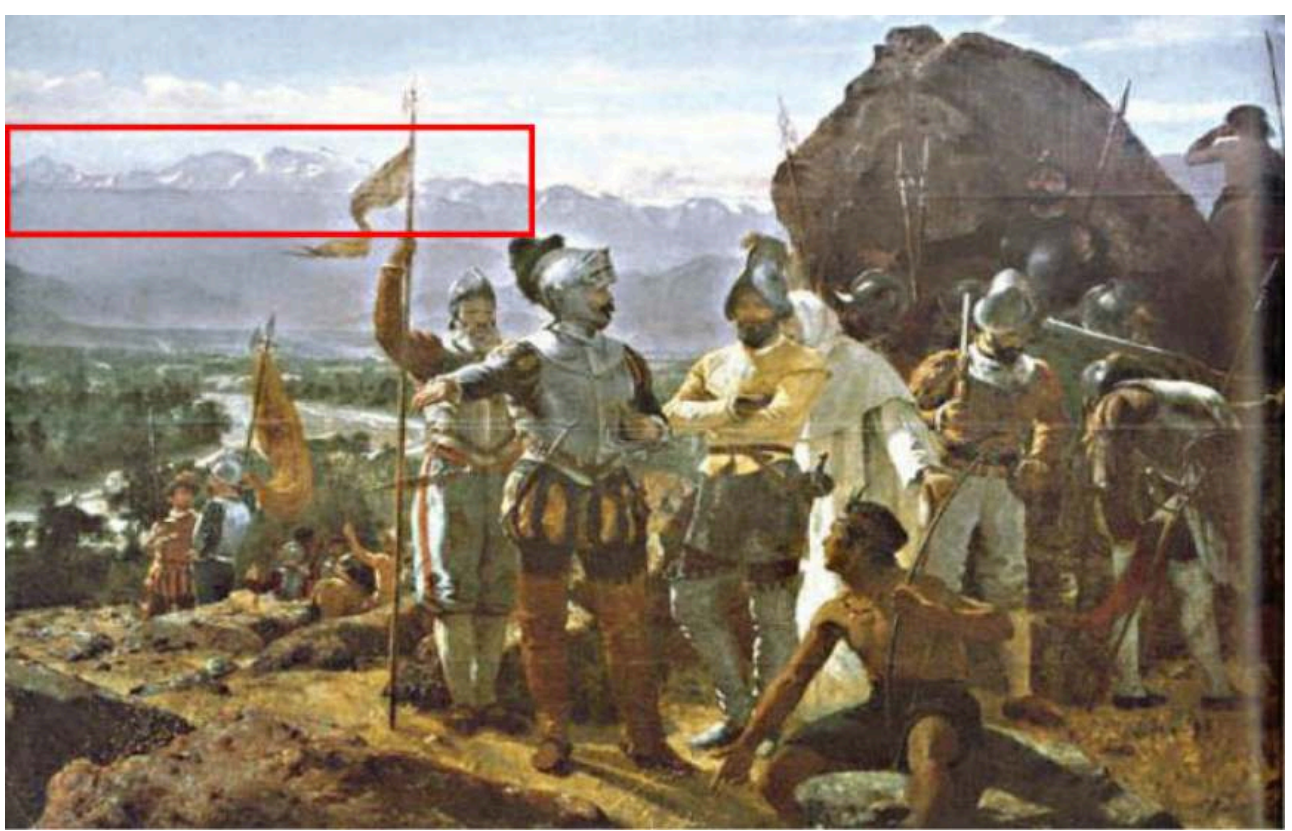

Óleo sobre tela, $250 \times 13400 \mathrm{~cm}$

Colección Museo Histórico Nacional

27 Como vemos, la obra de Rugendas es central en la construcción de esta primera vista de la secuencia. El artista llegó a Chile en 1834 (seis años después de Gay), siendo ya un pintor reconocido puesto que había recorrido Brasil (Voyage Pittoresque dans le Brésil, París 1827) y México. El mismo año de su llegada, para las fiestas de septiembre, el gobierno le encargó una pintura, que hoy se llama La llegada del presidente Prieto a la pampilla (1834) (Fig. 11). Se trata de un cuadro oficial, que muestra en el primer plano la comitiva presidencial llegando al lugar de las fiestas populares de septiembre. José Joaquín Prieto fue el primer presidente de los regímenes decenales conservadores 
regidos bajo la Constitución de 1833 que expresa la concepción del poder del ministro Diego Portales. El historiador Luis Mizón hace un interesante estudio en el que contextualiza el trabajo de Gay en Chile, en un periodo que corresponde también a la estadía de Rugendas en el país. Según este autor, en palabras de Portales 'el gobierno que le parece más apropiado para Chile es fuerte y centralizador, capaz de imponerse a las fracciones y mantener el orden interno y el bien público del Estado" (Mizón, 2001: 37). Según Mizón la concepción autoritaria de Portales no es solo su creación, sino que respondería a una trayectoria de autoritarismo y a la prolongación de la colonia en la república. Esta idea del gobierno fuerte y centralizador influye en la construcción de un paisaje que, aun cuando se realiza desde la visualidad de Santiago como capital, aspira a representar a la nación.

El trabajo del arquitecto Germán Hidalgo (2007) que estudia el cuadro La llegada del presidente Prieto a la pampilla en el contexto del rol del panorama en la transformación del Santiago durante la segunda mitad del siglo XIX, demuestra notablemente que el fondo real de la pampilla no coincide con el pintado por Rugendas en el óleo (por no corresponder el ángulo visual), sino que el pintor optó por usar como escenario de la historia el telón de la cordillera nevada, que aparece en la primera vista de Santiago del Atlas de Gay: Santiago (Litographie par Duppressoir d'après un croquis de M. Rugendas) (ver Figs. 10 y 11). En esa lámina se muestra la ciudad a lo lejos, desde el acceso al valle por el camino de Valparaíso, que es la ruta por la que llegaba la gran mayoría de los viajeros del siglo XIX desembarcados en el puerto. Por lo tanto, este fondo no es natural, sino una opción. La misma opción que, como se verá, se reitera desde el cerro Santa Lucía.

Entre el punto de vista del acceso a Santiago por el camino a Valparaíso y el del Cerro Santa Lucía hay más de $10 \mathrm{~km}$ de distancia, siguiendo el mismo eje visual. El pequeño cerro ubicado a solo cuadras de la Plaza de Armas, centro de la ciudad de Santiago desde su origen, es el punto de vista que elige Rugendas para el pequeño óleo Recuerdo de Santiago de 1843 y que corresponde a la misma imagen que selecciona Gay para la lámina Vista del Valle del Mapocho. En esta se explicita que se trata de una litografía hecha a partir de dibujos de Rugendas y Gay (Figs. 6 y 7). Hay que destacar también, que tomar al Cerro Santa Lucía como mirador de la ciudad y su entorno no era un gesto nuevo. Por ejemplo, ya lo había visitado y luego descrito el expedicionario francés Amédée Fréziér (1711) y Charles Darwin (1834-35).

Resulta notable constatar que en estas cinco imágenes, usando dos puntos de vistas distintos (el acceso a Santiago desde Valparaíso y luego el Cerro Santa Lucía), se construya un paisaje a partir de un recorte particular del continuo de los Andes, que luego se reproduce y difunde a lo largo de 50 años. Es esta elección y reiteración del fondo lo que actúa como un mecanismo de producción del paisaje nacional.

31 Recortar una parte del continuo indivisible que es la naturaleza, es para Simmel el proceso por el cual la naturaleza se convierte en paisaje y que por esa misma vía deja de ser natural. "La naturaleza, que en su ser y sentido profundo nada sabe de individualidad, es reconstruida por la mirada del hombre que divide y que conforma lo dividido en unidades aisladas en la correspondiente individualidad [que llamamos] paisaje" (Simmel, 1996: 370). Pero, ¿por qué Rugendas recorta esos cerros y no otros? (Fig. 12). Esto se podría explicar en parte por su sensibilidad como artista, que lo lleva a descubrir e inventar un punto de vista particular; pero más allá de eso, la hipótesis de 
este trabajo apuesta a que el artista actúa como un muy buen intérprete y como una pieza de una construcción histórica.

Fig. 10. J.M. Rugendas. “Santiago", 1854

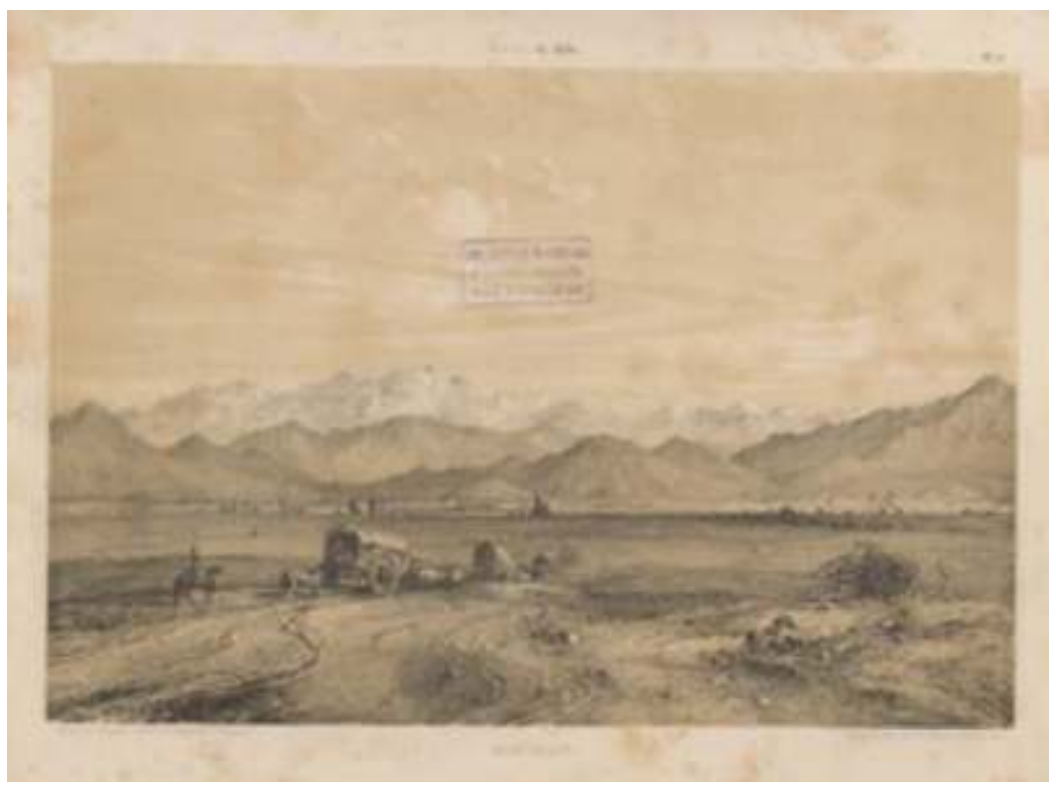

Litografía, en C Gay, Atlas de la historia física y política de Chile

Fig. 11. J.M. Rugendas. Llegada del Presidente Prieto a La Pampilla, c. 1834

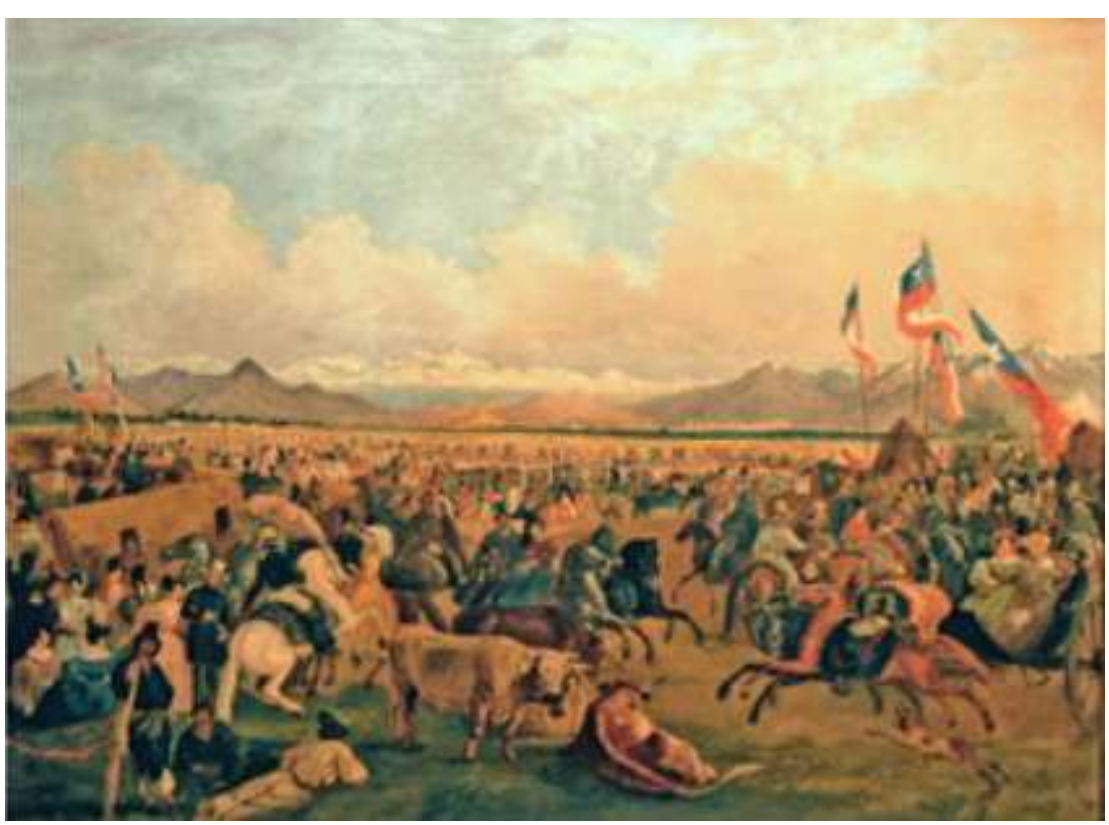

Óleo sobre tela, $70 \times 92 \mathrm{~cm}$

Colección Museo Nacional de Bellas Artes 
Fig. 12. Detalle de la Cordillera de El Plomo en La Llegada del Presidente Prieto à La Pampilla

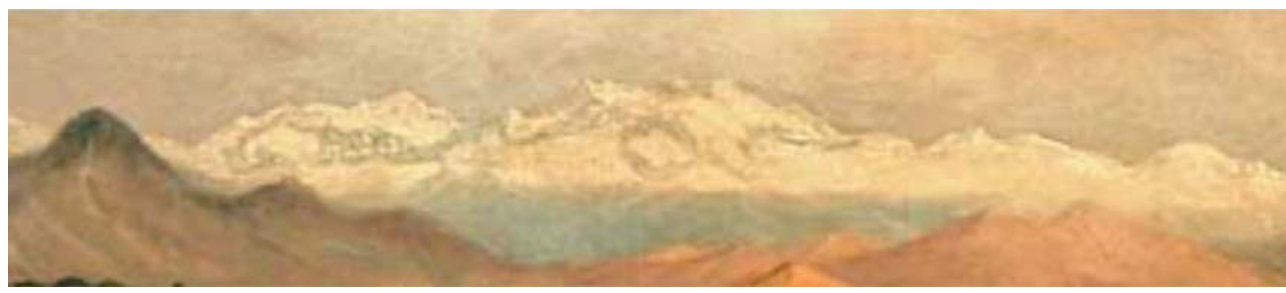

El historiador brasileño Pablo Diener, autor de excelentes trabajos sobre la obra de Rugendas, estudia al artista en el marco de la categoría de lo pintoresco, un término que le ayuda a entender el trabajo de los artistas viajeros y seguidores de Humboldt. Para este autor, lo pintoresco en América sobrepasa el sentido inicial de pintar ciertas vistas excepcionales, para jugar más bien un papel performativo: mostrar cada ambiente como un arquetipo identificable, que sintetiza aspectos de la geografía física y de ciertos tipos y costumbres asociados a ese ambiente. Desde la elección de su ruta por América, Rugendas sigue este sentido: "el artista viajero no registró todo y cualquier paisaje por donde pasó, sino que definió una selección claramente identificable”: en Brasil fue la selva virgen, en México, la selva en la Sierra Madre Oriental y el paisaje volcánico y en Chile, el paisaje cordillerano de los Andes (Diener, 2007: 296). En el caso de los volcanes de México y el paisaje cordillerano de los Andes, Rugendas sigue claramente la huella de Humboldt (Ensayo sobre la geografía de las plantas (1805); Vistas de cordilleras (1810)), ensamblando arte y ciencia selecciona las altas cumbres majestuosas, nevadas y de fisonomías particulares. Esto explica que el recorte de Rugendas corresponda a las cordilleras de El Plomo, que se ajustan exactamente a ese modelo, sintetizando la aproximación estética y científica, que incluye el saber del mapa. Rugendas ayuda así a construir un arquetipo identificable: el paisaje de la cordillera nevada como telón de Santiago y de paso, de la joven nación chilena.

Es interesante comentar un aspecto que ayuda a entender que esta elección va más allá del artista y que corresponde a un recorte dentro de su obra. Para Diener, las primeras obras del autor en Chile (que son justamente las del período estudiado) no presentan ninguna continuidad y consistencia en términos plásticos, como sí ocurre con su trabajo sobre la alta montaña, realizado a partir del paso de los Andes en 1837. Curiosamente, estas obras en Chile han tenido muy poca difusión y no forman parte de ninguna colección oficial, en cambio las comentadas, ya sea a través de las láminas de Gay o las pinturas de asunto histórico o costumbrista, han tenido una amplia difusión. En ese sentido, se busca responder a la cuestión acerca de lo que pintó o no Rugendas considerando que parte de su obra fue pintada por encargo del gobierno y que con el tiempo, se produjo una selección de esta para convertirse en parte de un discurso oficial.

La segunda imagen de esta secuencia es el grabado en madera Santiago. Vista jeneral tomada del cerro de Santa Lucía (Fig. 8) que aparece en el libro Chile Ilustrado: guía descriptiva del territorio de Chile, de las capitales de Provincia, de los puertos principales de Recaredo Tornero ${ }^{3}$, impreso en París en 1872. A pesar de su gran importancia como obra científica fundacional del conocimiento de Chile, el Atlas de Gay tuvo una difusión restringida durante el siglo XIX debido a su envergadura, el alto costo y el bajo tiraje. Según Sagredo, el tiraje fue de alrededor de 1250 ejemplares, 400 para el gobierno de Chile (que los distribuyó especialmente en sus misiones en el extranjero) y el resto fue comercializado por el propio Gay. Se difundió en los círculos intelectuales, pero solo 
cien años después, en 1967, el historiador Sergio Villalobos realizó una reedición parcial de las láminas en el álbum Imagen de Chile histórico (SAGREDO, 2004: 36-41). En cambio, el libro de Tornero se propone como objetivo explícito ser una obra de difusión y propaganda dirigida a un amplio público. No tiene pretensiones de estudio científico, sino de ser una compilación del conocimiento existente sobre el país, integrando estadísticas e informes oficiales, según señala el propio autor en el primer párrafo. "Al emprender la publicación de este libro, solo hemos tenido en vista el deseo de ofrecer al extranjero i a nuestros compatriotas, una reseña exacta i circunstanciada del estado de progreso material que ha alcanzado nuestro país" (Tornero, 1872: V). Tornero se preocupa de destacar en las primeras páginas, a través de una lista bibliográfica, que su obra se basa en los más importantes estudios recientes, en especial los trabajos del naturalista y minerólogo Ignacio Domeyko, del naturalista alemán Rodulfo Amado Philippi ${ }^{4}$, de Pissis y Gay, entre otros.

El libro, de alrededor de 500 páginas, está dividido en tres partes. La primera expone en detalle las características y estado de desarrollo por provincias, partiendo por Santiago y Valparaíso, que con unas 100 páginas cada una (dos quintos de toda la obra) ya dan cuenta de la mirada centralista del país. La segunda parte es una descripción general del país, para lo cual se divide el territorio en tres grandes regiones que se distinguen por su función productiva: "minera, agrícola i selvática" y que según señala el autor, están claramente delimitadas. La primera, al norte del río Aconcagua y hasta la provincia de Atacama, la segunda al sur de ese río hasta el río Biobío y la tercera desde el Biobío a la Isla de Chiloé. Finalmente en la tercera parte de la obra, "Tipos y costumbres", Tornero entrega un panorama de las características de la sociedad chilena siguiendo el modelo costumbrista usado por Rugendas y Gay.Es en este contexto aparece la figura Santiago. Vista general como la segunda imagen del libro, en la tercera página. La primera es el retrato del Presidente Federico Errázuriz, lo que muestra el sentido oficial de esta obra que ofrece la vista de Santiago como la primera imagen de la nación que se muestra a los extranjeros y compatriotas. Se trata de uno de los 200 grabados que reproduce el libro, cantidad que da cuenta del papel central que tienen las imágenes en la publicación. La utilización de una nueva técnica de grabado en madera hizo posible mejorar la calidad de las reproducciones e intercalarlas al texto, lo que significó una relación de simultaneidad entre imagen y texto (Rolle, 2011). En general en los grabados del Chile Ilustrado no figura el nombre del autor pero se puede deducir que la fuente usada ya no es solo el dibujo, sino también la fotografía, que hacia 1870 ya era una industria incipiente en Valparaíso, donde ya se habían instalado nueve estudios fotográficos, según registra el propio Tornero (TORNERO, 1872: 188). En el título de la Vista de Santiago se agrega "tomada" desde el cerro Santa Lucía, por lo que es posible que Tornero y el grabador conocieran y usaran como base la fotografía del francés Eugène Maunoury, quien había visitado Valparaíso y Santiago en 1861 (ver la semejanza entre las Figs. 13 y 14). Es interesante destacar como el mismo punto de vista ya identificado, pasa del dibujo y la pintura a la nueva técnica de la fotografía.

36 Tornero vuelve a optar por la vista oriente, la del valle fértil y la cordillera nevada, que es el arquetipo identificable de Rugendas y Gay, aun cuando en la descripción de la ciudad explica que esta se ha extendido hacia el norte y sobre todo hacia el sur, y en ningún caso hacia el oriente, donde se ubican mayoritariamente chacras y se distinguen los Tajamares del río Mapocho y los álamos que lo bordean. En el rótulo del grabado, Gay hablaba del valle del Mapocho, en cambio Tornero presenta su imagen como una vista de Santiago. Por otro lado, comparando con la fotografía de Manoury, donde la 
cordillera nevada aparece difusa, el grabador que la toma como modelo la vuelve a destacar como una estela blanca, uniformándola hasta el punto de que se distinga con menos claridad la silueta de las cordilleras de El Plomo.

\section{Fig. 13. "Santiago. Vista general tomada del cerro de Santa Lucía", 1872}

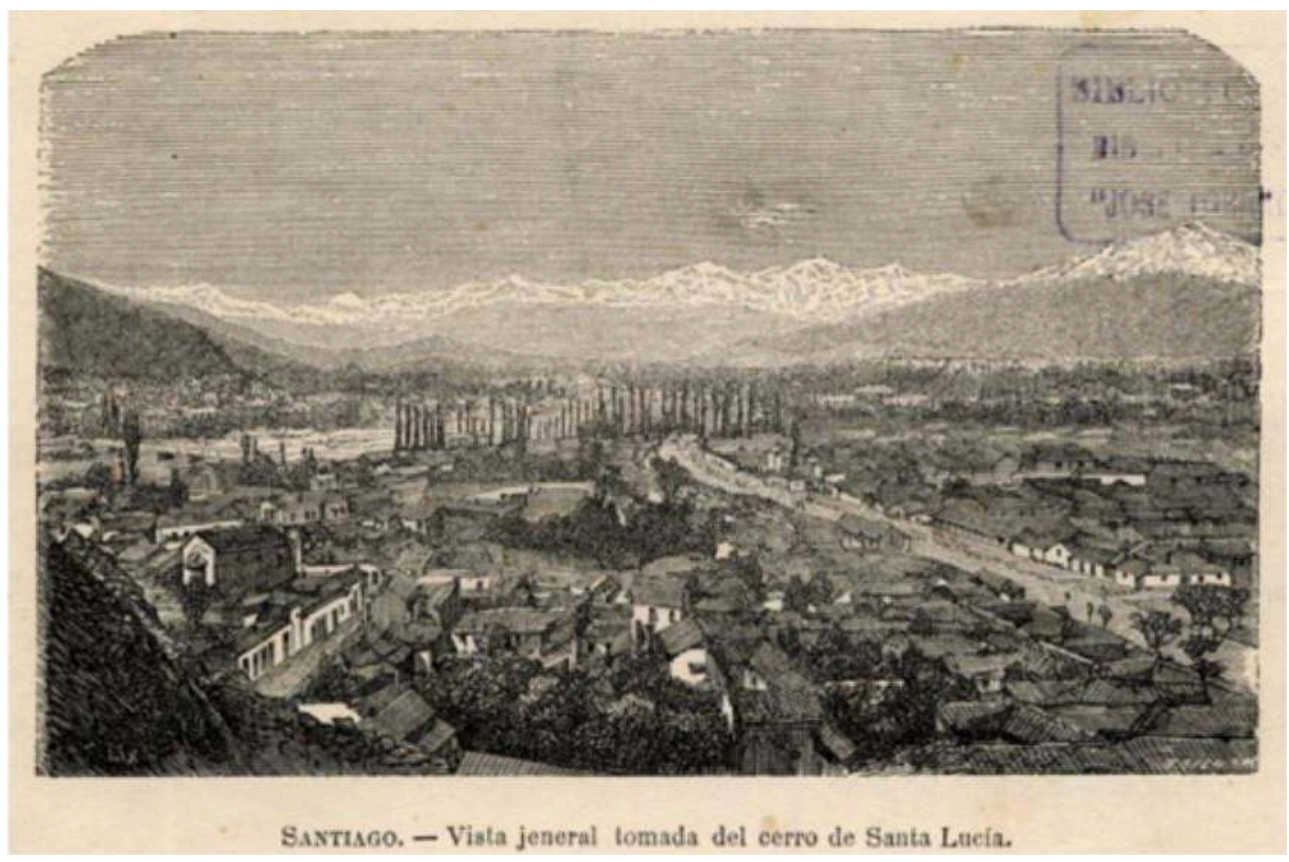

Grabado en madera, en R. Tornero, Chile Ilustrado

Fig. 14. E. Maunoury. " Vue générale », c. 1860-1870

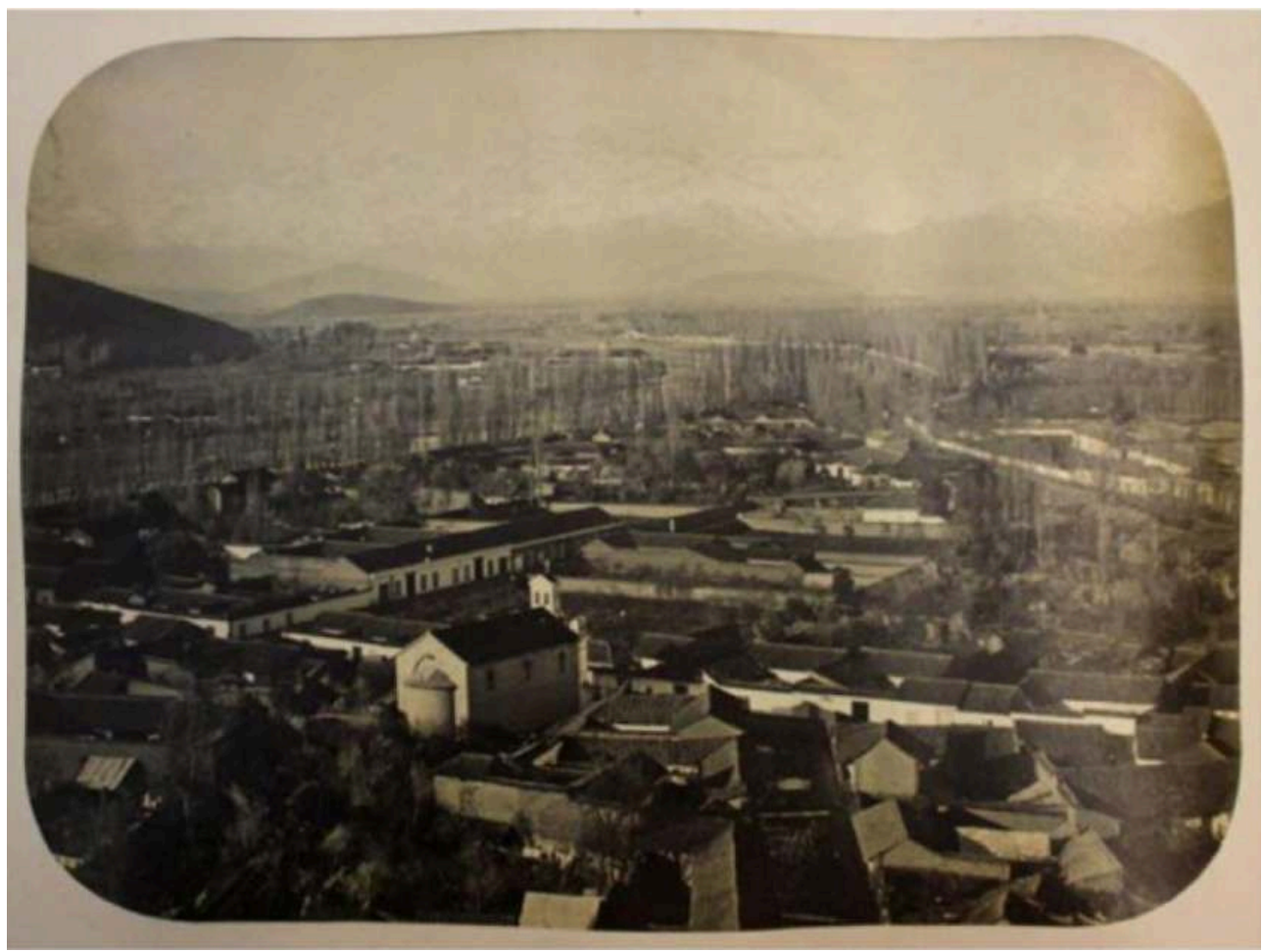

Fotografía, Archivo Bibliothèque Nationale de France, en archivovisual.cl. 

es así que se encuentra el correlato de la imagen en la descripción de la Jeología, que sigue justo a continuación del relato de la fundación de Santiago. Luego de señalar que la ciudad capital "vino a quedar situada en la rejion central del pais, en un hermoso valle que se estiende de Norte a Sur", el autor describe la vista hacia el oriente:

Por el lado del Oriente se divisan desde la ciudad varios cerros i cadenas que pertenecen a la gran cordillera de los Andes. En el mismo paralelo de Santiago se encuentra el gran pico del Tupungato, que tiene una elevación de 6,710 metros; en seguida el cerro El Plomo, que es uno de los mas hermosos panoramas que se ven, desde la ciudad, coronado en todo tiempo de nieve i cuya altura alcanza a 5,433 metros; después el cerro de Peñalolén, visible también desde la ciudad, i que tiene una elevación de 3,245 metros. (Tornero, 1872: 3).

En el texto destaca y adjetiva el cordón de El Plomo, volviendo a aparecer el ensamble entre apreciación estética y el saber científico como la huella de Rugendas, Gay y Pissis.

Aun cuando Tornero no lo señala entre sus fuentes, sus descripciones están basadas no solo en Domeyko, Pissis o Gay, sino en un hermoso texto escolar escrito por su padre, Santos Tornero: el Manual de Jeografía. Conforme al programa de la Universidad de Chile y siguiendo el plan de las lecciones de jeografía moderna de D. José V. Lastarria (1864, Imprenta el Mercurio, Valparaíso). En esa pequeña obra, después de presentar Europa, España y todos los continentes, se describe Chile y con gran detalle los países vecinos, en particular Argentina, situando al país en medio de su contexto Sudamericano. Es un texto lleno de adjetivos y apreciaciones estéticas en el cual se habla de las montañas:

Cordilleras. A medida que es bello cuanto en estos sitios se presenta, es imponente y majestuosa la vista de la cordillera que se estiende hácia la parte oriental, recorriendo la república de N. a S. Esta gran cadena tendrá 40 leguas de ancho, y no es mas que una sucesión de montes altísimos llenos de precipicios espantosos, cubiertos perpetuamente de nieves, entre los cuales hai espaciosos y amenos valles, regados por las vertientes que se precipitan de las altas cumbres. (Tornero, 1864: 100).

Lo interesante del Chile Ilustrado es su inserción en la industria editorial y la imprenta, que para Benedict Anderson (1993) es el cambio tecnológico que permite la aparición de esa comunidad imaginada que es la nación. Recaredo Tornero es hijo de Santos Tornero, un español que en 1834 llegó a Valparaíso y que junto a sus hijos jugó un rol central en el desarrollo de la imprenta e industria editorial en Chile, abriendo las primeras librerías de Valparaíso, Santiago y otras ciudades, editando textos escolares, libros, revistas, folletines y periódicos. En 1842 compró el diario El Mercurio de Valparaíso y su imprenta, la que modernizó con nuevas maquinarias traídas de Estados Unidos, convirtiéndola en el centro de publicación de mapas, textos oficiales y libros ilustrados más importante del país. A partir de entonces, El Mercurio y la casa editorial fueron canales de expresión para los movimientos literarios y liberales del siglo XIX. Intelectuales chilenos y de otras naciones americanas de la talla de Sarmiento, Bello, Lastarria y Vicuña Mackenna colaboraron en el periódico. Recaredo Tornero dedicó su obra a este último, quien en ese momento ejercía de Intendente de Santiago. El Chile Ilustrado, como los textos escolares son piezas de un mecanismo de difusión y masificación de un discurso central sobre qué es Chile, cómo se le imagina y por lo mismo, cómo se proyecta.

41 A diferencia del Atlas de Gay, la obra de Tornero ha sido escasamente estudiada, pero fue reeditada en el 2011 en el marco de los festejos del bicentenario de la independencia 
nacional. En el texto introductorio, Claudio Rolle señala que este libro es "una de las mejores expresiones de la autopercepción de los chilenos y de la fascinación ejercida sobre ellos por una cierta idea de progreso que, en las páginas del Chile ilustrado, ofrece una vigorosa y nítida visualización" (Rolle, 2011: IX). Según este autor, la obra representa a una nueva burguesía comerciante, minera e industrial que se muestra a sí misma y busca difundir en el extranjero la idea de Chile como una nación vanguardista, la más civilizada de Sudamérica: en palabras de Tornero "la primera por la que cruzó un ferrocarril", pionera en "unir sus ciudades con alambre eléctrico" o en contar con un sistema de instrucción pública como los países europeos. La obra recibió un premio en el certamen de libros de la Exposición Internacional de Filadelfia de 1876 y se convirtió, según Rolle, en una carta de presentación del país en el extranjero y en el mejor retrato de este en la segunda mitad del siglo XIX (ídem: X-XXVIII).

Después de Rugendas, Gay y Tornero la tercera imagen que cierra esta secuencia, en la que se reitera un punto de vista, es la pintura La Fundación de Santiago de Pedro Lira, 1888 (Fig. 9). Un cuadro de grandes dimensiones ( $2,5 \times 4 \mathrm{~m}$ ), que presenta en su centro a un grupo de soldados españoles de pie, vestidos, calzados y con cascos, entre los que se distingue a Pedro de Valdivia por la armadura y el gesto con que indica con el brazo extendido hacia el valle. A sus pies, un indio, semidesnudo, sentado sobre una roca, señala el lugar donde fundar la ciudad. Atrás se ve serpenteando el río, el "valle fértil" y al fondo, las cordilleras nevadas de El Plomo. Igual que en la Llegada del presidente Prieto a la pampilla de Rugendas, el pintor seleccionó el escenario de la historia. Selecciona primero el cerro Santa Lucía, que veinte años antes el intendente Benjamín Vicuña Mackenna había transformado en un paseo público. Y luego, la vista hacia el oriente, dirección que no corresponde precisamente a la que mejor muestra el emplazamiento de la antigua ciudad de Santiago, como lo muestran por ejemplo otras pinturas de Rugendas o los panoramas de los artistas viajeros ingleses James Melville Gillis (1855) y T.R. Harvey (c.1860) que representan el centro histórico de la ciudad desde las terrazas del Cerro Santa Lucía que miran al poniente (Pérez de Arce, 1993: 142-143). La pintura de Lira es parte de la producción de una pintura histórica común a varios países americanos en la segunda mitad del siglo XIX e inicios del XX. Así como Lira funda Santiago en el imaginario 300 años después de la llegada de Valdivia, en 1904 Pedro Subercaseaux pinta El descubrimiento de Chile por Almagro. Ambas pinturas destacan un "momento primitivo, sagrado, del nacimiento de la nación" (Coelho, 2009: 173). En ambos casos, la nación nace con la llegada de los españoles presentados como soldados vencedores frente a indios que, en forma pacífica y sumisa, ofrecen el territorio. Crear la nación implicaba delimitar y describir el territorio, que es lo que vienen haciendo Gay, Pissis y Tornero, pero además, contar una historia. La pintura de este género cumple el papel de ensamblar territorio e historia. Pero no es solo el relato de la independencia, que ya había aparecido en pinturas previas, como La llegada del Presidente Prieto o La Batalla de Maipú, que había pintado Rugendas en 1837, sino de la invención de una tradición. La joven nación, que todavía no cumplía para ese entonces ni cien años, se inventa en el imaginario un origen, que le da un horizonte histórico de trescientos años.

El mismo Pedro Lira fue una figura central en la constitución de una pintura nacional. Estudió leyes y pintura, vivió en París (1874-84), como era común entre la alta burguesía de la época y como sus contemporáneos Recaredo Tornero y Vicuña Mackenna. Al regresar, participó en la organización de los primeros Salones de Pintura y del Museo de Pintura de la Quinta Normal, antecesor del Museo Nacional de Bellas 
Artes y fue el primer director chileno de la Escuela de Bellas Artes durante veinte años. Su momento histórico es el de Vicuña Mackenna, que lo elogia como un "promisorio pintor" en 1884. Es el momento de la "ciudad primada" (como la llama el historiador Armando de Ramón), cuando una elite burguesa y vanguardista, que había vivido el auge económico de la minería de la plata, proyecta la modernización de Santiago y de Chile según el ideal progresista que exponía Tornero.

Una obra emblemática de la modernización de la ciudad según este modelo es la transformación del cerro Santa Lucía, que pasa de ser un peñón -que por entonces era usado como cantera y basural, despreciando su condición de mirador privilegiado de la ciudad- a un paseo aéreo, siguiendo la imagen de los parques europeos y que, a su vez, responde a la intención de construir una ciudad-capital moderna, bella e identificada con su particular geografía. La transformación del cerro es una de las obras del plan de reurbanización de Santiago que dirige Vicuña Mackenna y que incluye la vía circunvalatoria conocida como Camino de Cintura, el parque Cousiño y otras obras tan significativas, pero de largo plazo, como la construcción de un sistema de alcantarillado y agua potable. El cerro es seguramente una de las obras más visibles del plan, por su céntrica ubicación y por la rapidez con que se desarrollaron las obras. Aunque posteriormente se extendieron hasta 1940, en dos años (1872-1874) Vicuña Mackenna había logrado hacer los cambios fundamentales, difundidos en un álbum fotográfico publicado con motivo de su inauguración en 1874. Entre las obras del cerro, se transformó una antigua prisión y fortaleza en el Museo Histórico-Indijena, donde se instaló la "Exposición del coloniaje" que Vicuña Mackenna había organizado en 1873, dando un primer paso hacia la construcción de un museo histórico nacional (Schell, 2003). Otro aspecto significativo del proyecto del cerro es la lucidez y habilidad de Vicuña Mackenna para convertirla en una obra colectiva de la elite republicana en la que participaron en forma voluntaria ingenieros y topógrafos y donde los monumentos y estatuas se consiguieron gracias a la colaboración y financiamiento privado más que municipal.

Este es el lugar que dos décadas más tarde elige Lira como escenario de la fundación de la ciudad, reiterando el punto de vista que recorre el siglo, situado en el lugar que, tras las reformas mencionadas, pasó a ser el paseo privilegiado de la elite santiaguina. La obra obtuvo Segunda medalla en la Exposición Universal de París de 1889, fue comprada por el Estado chileno para la Colección de Arte Nacional y hoy se expone en el Museo Histórico Nacional, donde está ubicado en un lugar de primera jerarquía. Es una imagen que ha sido ampliamente usada en los libros de historia de Chile, en textos escolares y aun en billetes.

La secuencia funciona como un mecanismo de la construcción cultural de la cordillera como paisaje nacional, la cual continúa reproduciéndose durante el siglo XX hasta la actualidad. 
Fig. 15. Sello postal, 1941

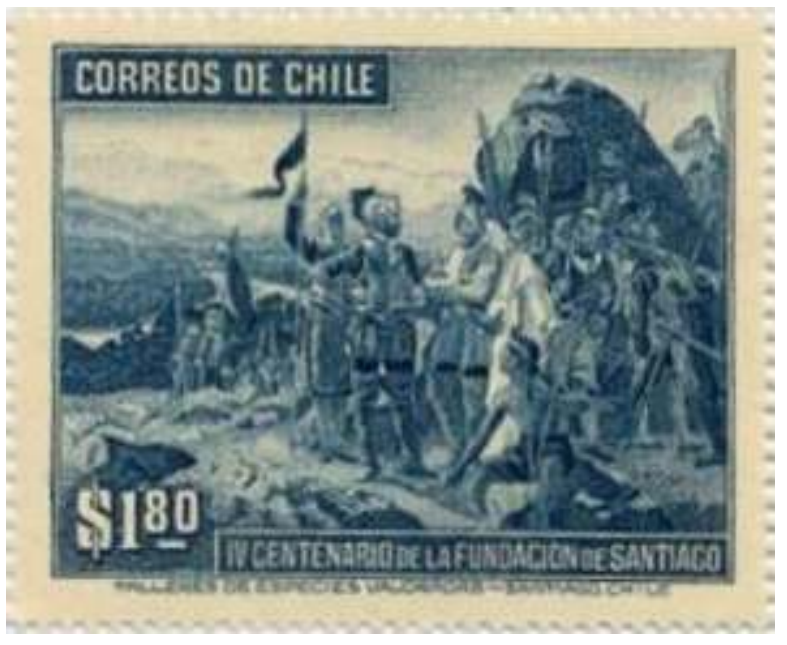

Correos de Chile

Fig. 16. Billete de 500 pesos, $1875-2008$

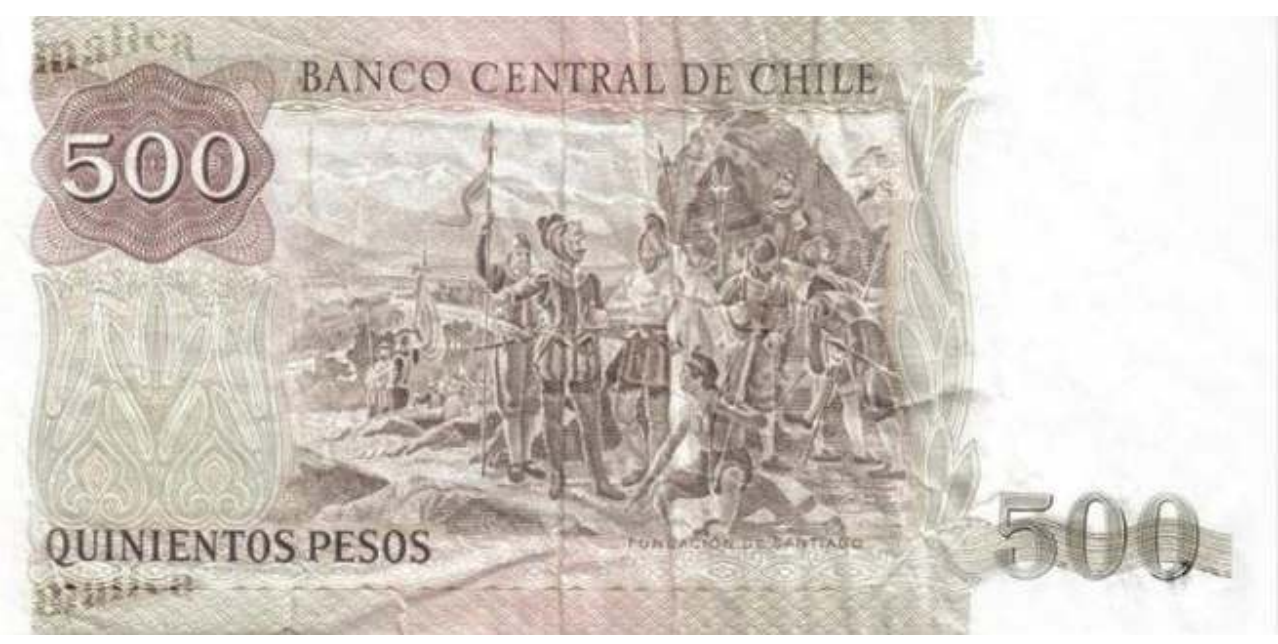

Banco Central de Chile

\section{Arrieros y vaqueanos: esos personajes que recorren el vacío}

En su libro Ojos Imperiales, Mary Louise Pratt señala que los artistas y científicos viajeros del siglo XIX reinventan América en el imaginario, como si se tratara de un espacio vacío, virgen, aun por descubrir, a pesar de los 300 años transcurridos de colonia española, abundante en riquezas y materias primas disponibles para una nueva expansión económica europea. Según Pratt, este imaginario europeo es asimilado por las elites criollas al convertirse estas en los grupos hegemónicos de las nuevas naciones. La imagen de una tierra despoblada tranquiliza frente a las importantes revueltas indigenistas que se habían producido en las últimas décadas del siglo XVIII. Las elites construyen así una nación blanca y eurocéntrica, de paisajes sublimes y con economías basadas en la explotación de materias primas, realizada ya no por los españoles sino por los criollos con capitales europeos, principalmente ingleses. Se instaura así un 
modelo que niega y excluye a los grupos marginados de la sociedad, aquellos personajes secundarios que quedan excluidos de la historia nacional: indios, pobres, pueblo, clase obrera, popular o subalternos (Beverly, 1995).

El Atlas de Gay, las obras de Rugendas y el libro Chile Ilustrado no se ajustan estrictamente al modelo del espacio vacío, que sí rige al Atlas de Pissis. La descripción del territorio en estos tres primeros casos no se hace solamente desde la mirada, sino que conjuga el ver y el hacer al que se refiere Michel de Certeau, lo que se manifiesta en la estructura de las obras, que incluyen junto a los mapas y vistas, un número importante de escenas y tipos costumbristas. El trabajo de Gay, además de las montañas nevadas como telón de fondo constante que aparece en las vistas, incluye escenas y láminas costumbristas en las que se aprecia una mayor diversidad en la representación de cerros, con y sin nieve. Estas láminas muestran una pluralidad de actividades y personajes asociados en especial a la ganadería, la minería y el trasporte. Entre las escenas, hay varias que muestran la vida de montaña, tales como Una Matanza, Caza a los cóndores y Ternero atacado por los cóndores. Entre las láminas con personajes más bellas y cuidadosamente coloreadas del Atlas están Mineros, situada en un cajón cordillerano y Carretero - Capataz, que tiene como fondo unos picos nevados, de fisonomía más alpinos que andinos. Para otra de estas escenas, Gay escoge un dibujo de Rugendas. Se trata del Paseo a los baños de Colina, Santiago (F. Lehnert d'après Rugendas) (Fig. 17). Al centro va una carreta cubierta con lona, con varias mujeres al interior, una tocando la guitarra. $\mathrm{Al}$ fondo se ven los cerros nevados y alrededor de la carreta, el dibujante congrega a varios de los personajes que incluyó en el Álbum de Trajes Chilenos (1838)5: el lacho, el huaso, el carretero y el arriero. Este último, ubicado en el margen, se distingue por la mula, de orejas más largas que el caballo, y que es el animal usado para cruzar las cordilleras. El arriero y su mula son los personajes característicos de la montaña del siglo XIX (Fig. 18). Es interesante destacar que en esta lámina, como en La chingana, una fiesta popular ambientada en la precordillera de Santiago, el lugar aparece como un espacio de paseo y de fiesta, donde los personajes conviven en un ambiente de integración social. 
Fig. 17. J.M. Rugendas. Paseo a los baños de Colina", Santiago, 1854

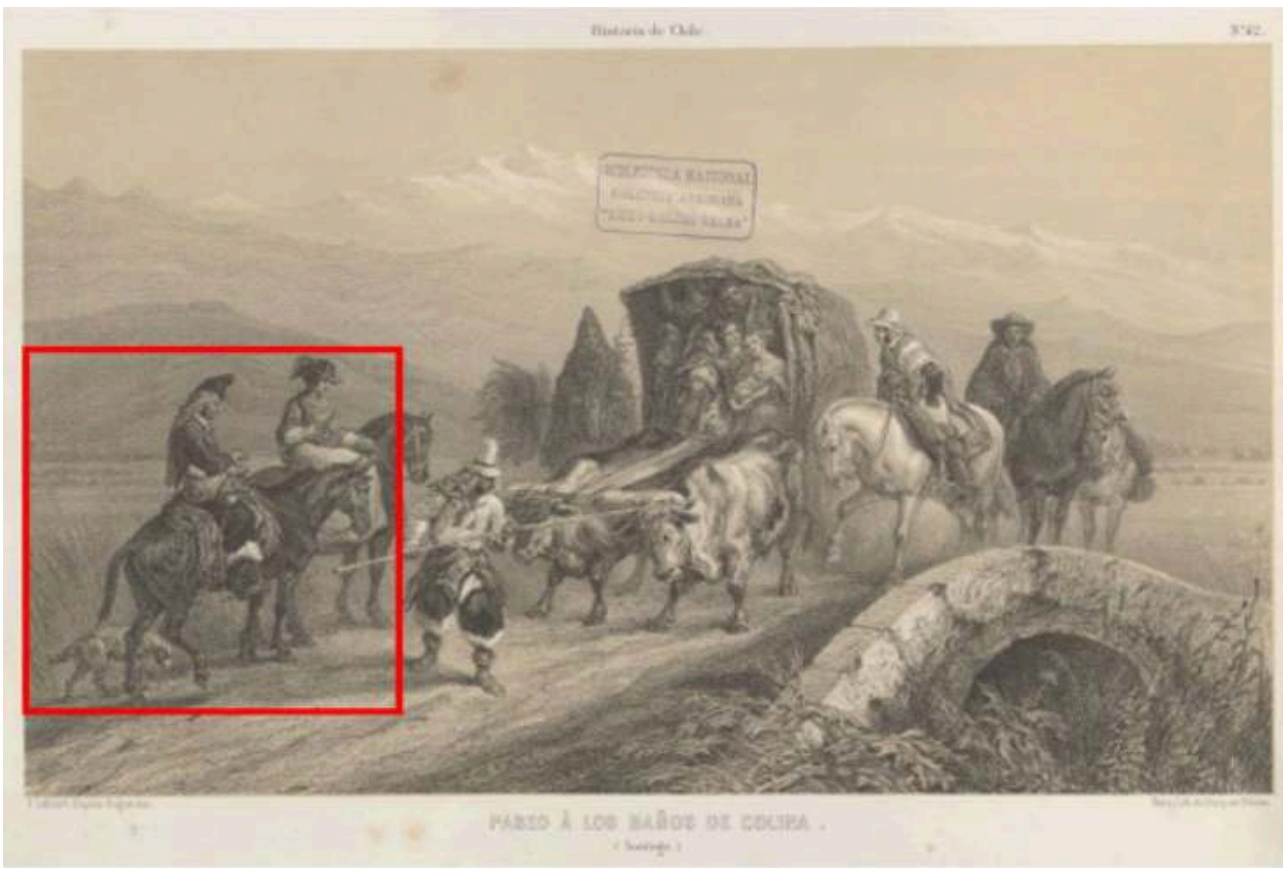

Litografía, en C. Gay, Atlas de la historia física y política de Chile

Fig. 18. J.M. Rugendas, Arriero, 1838

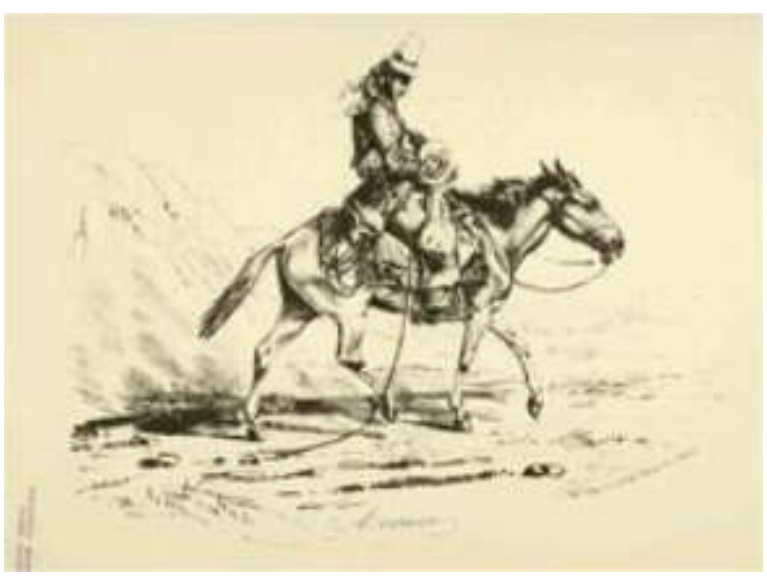

Litografía, en Álbum de trajes chilenos 
Figs. 19 y 20 . El hacendado y El Arriero, 1872
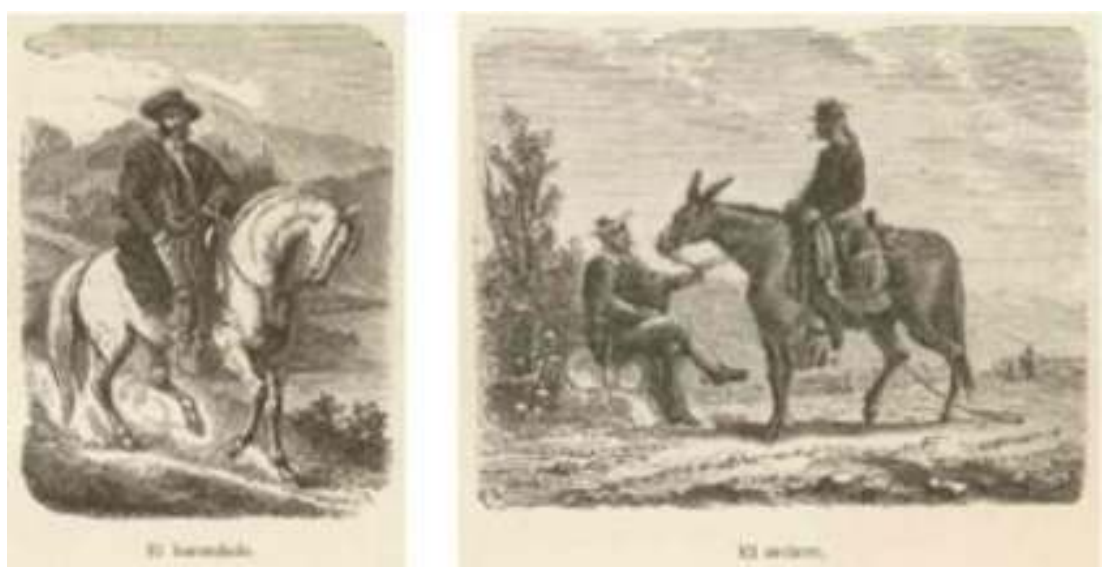

Grabado en madera, en R. Tomero, Chile ilustrado

En el caso del Chile Ilustrado de Tornero, el autor dedica la tercera sección del libro a los Tipos y Costumbres y vuelve a actuar como difusor de Gay y Rugendas al reproducir en calidad litográfica dos escenas del Atlas, La Matanza y La Trilla. Aun cuando los grabados en madera de los personajes son de formato pequeño y baja calidad plástica, las descripciones y juicios que entrega el texto son un aporte significativo. Al describir la mayor hacienda del país, "La Compañía", Tornero muestra en primer lugar el papel complementario que tenía la montaña dentro del sistema agrícola de la zona central:

Esta parte [de la hacienda] se subdivide en dos: la primera ocupa la parte más próxima al camino real, i en ella se encuentran los valles mas estensos i mas fértiles, que son dedicados al cultivo del trigo i otros cereales de menos importancia. La segunda parte, situada hacia la cordillera, comprende todas las cerranias que se desprenden de esta, así es que sus terrenos planos son mui pocos, estrechos i profundos. La mayor estension es ocupada por los cerros. Estos son montuosos i pastosos, i en ellos se cría actualmente un número que no baja de veinte i cinco a treinta mil animales vacunos. (Tornero, 1872: 429).

Al introducir los Tipos y costumbres, el autor usa como modelo el relato del itinerario. Le propone al lector hacer una rápida excursión por las calles de Santiago “...entrar en el humilde rancho del pobre, así como en el suntuoso palacio del aristócrata; [donde] sorprenderemos a ambos en sus costumbres íntimas i bosquejaremos de paso los tipos más resaltantes de nuestra sociedad". Luego el itinerario sigue por el campo, “...donde encontraremos al inquilino agobiado bajo la volun tad del patrón convertido en señor feudal, i a su lado, formando un elocuente contraste, veremos alzarse la figura bravía y leal del vaqueano". Con ellos asistirá a las grandes actividades del campo: el rodeo, la matanza y la trilla. Curiosamente al final del párrafo dirige el texto a un público letrado femenino: “...el programa es tentador ¿no es verdad, lectora amiga?” (ídem: 445-446).

Tornero es agudo en marcar las diferencias entre los tipos y clases sociales, que agrupa en la aristocracia, el "medio pelo" y el pueblo. Diferencia al minero rico, "de nobleza no más antigua que Chañarcillo", del minero pobre ("apir" o "barretero") que tiene una alta opinión de sí mismo, la que comparte el autor. En cambio, repitiendo la mirada centralista que como ya vimos domina el texto, al hablar del pueblo señala que a diferencia de los tipos regionales que existen en toda Europa, en Chile no hay diferencias regionales, todo el bajo pueblo es igual, habla el mismo lenguaje, "antigramatical", lleno de barbarismos y palabras quechuas (ídem: 466). 
52 En el campo contrasta al hacendado y al inquilino, con el vaqueano y el arriero (Figs. 19 y 20). El primero es el hombre viejo de campo, el señor feudal, un "semidiós", pero atrasado y rutinero, muy distinto del “agricultor moderno", que está introduciendo la mecanización. El inquilino es su vasallo, que vive con su familia en un sistema feudal, sin rebelarse contra el patrón. En contraste, al vaqueano y el arriero los presenta como personajes independientes y ligados a la fuerza de la naturaleza. El vaqueano viaja del valle a la montaña: sube y baja el ganado de las invernadas, al inicio de la primavera y al final del verano, se introducen por las gargantas de la cordillera, reuniendo a los animales. Tornero se seduce por el personaje y su medio, asociándolos ambos a la naturaleza:

... al admirar el trabajo que este efectúa en medio de su completa ignorancia, aislado en las inmensas llanuras de los Andes, cuyas nevadas cumbre se mantienen siempre a la vista del chileno, no podemos menos de rendir homenaje a la naturaleza i mirar con cierto desdén la civilización i las artes ! (ídem: 470)

El autor admira el trabajo del vaqueano, pero lo asimila a un estado natural, no reconoce en él una cultura diferente sino la "completa ignorancia". Se muestra atrapado en la dualidad entre naturaleza y cultura, seducido tanto por la barbarie como por la civilización.

Por su parte, el arriero es, para Tornero un personaje que se irá extinguiendo en la medida que se extienda el ferrocarril y lo reemplace en el rol de transportista de mercaderías y pasajeros. Lo describe con sus mulas y tropas, "robusto i de fuerzas atléticas", creando un arquetipo que se ajusta al ideal progresista del autor:

El arriero, así como el vaquero, por encontrarse sin duda mas independiente i mas íntimamente ligado a la naturaleza, posee cierta altivez i cierta enerjía moral que se revela hasta en su fisonomía, mientras que el inquilino, avasallado bajo una voluntad casi siempre despótica, demuestra una humildad rastrera i un alma pequeña (ídem: 481)

El historiador mendocino Pablo Lacoste, en un estudio realizado a partir de los registros de transporte y comercio trasandino a fines del siglo XVIII y principios del XIX, muestra el dinamismo económico que existió en torno al cruce de los Andes y hace visible justamente al arriero como un sujeto histórico central en este espacio y que para este autor, fue pionero en la formación de la burguesía del Cono Sur (Lacoste, 2008).Tornero entonces está destacando las capacidades de un personaje que ya desde principios de siglo tenía un rol emergente dentro de la sociedad de siglo XIX y que demuestran que la montaña no es simplemente un espacio vacío sino un espacio social.

\section{Conclusiones}

La secuencia que va del Atlas de Gay a la pintura la Fundación de Santiago (que recorre medio siglo) demuestra que la representación de la montaña no es simplemente un reflejo del natural, sino un conjunto de elecciones y reiteraciones, que van transformando un fondo particular, el de las cordilleras nevadas de El Plomo vistas desde Santiago, en un paisaje arquetipo identificatorio de la capital. Al aparecer en lugar tan prominente y de forma reiterada en los diferentes soportes descriptivos de la nación, esta imagen se va convirtiendo en un paisaje nacional.

Se trata de un proceso que no se activa a partir de una obra individual, sino como una construcción colectiva, donde Gay y Pissis actúan como fundadores del conocimiento 
científico del país, Rugendas como un muy buen intérprete que aúna el saber con la experiencia y la visualidad, Tornero con un papel importantísimo en la divulgación y popularización del imaginario y finalmente, Lira que reinventa a través de la pintura académica, desde Santiago, el origen de la nación y le da trescientos años de historia a una nación que recién empezaba. En toda la secuencia, el Estado actúa como validador, al encargar o seleccionar expresamente ciertas obras que adquieren el carácter de un paisaje nacional. En la tarea de inventar la nación y consolidar al Estado autoritario, fuerte y centralizado que propone Portales, la montaña-arquetipo, vista desde Santiago, naturaliza la nación, diluye las diferencias y sirve para crear un sentido de unidad.

Cuestionando el tópico del espacio vacío, al mirar el detalle de imágenes como Caminos para cruzar las cordilleras y los relatos que están en los márgenes del foco central, la montaña aparece más bien como un espacio recorrido, vivido y ocupado. En el siglo XIX ella constituyó un espacio económico importante como lugar de ganadería, transporte y comercio, y un espacio de ocio complementario a la ciudad y al valle agrícola. Las representaciones de esta múltiple dimensión de la montaña, así como de su rol en la delimitación del territorio, constituyen un paso necesario para construir la comunidad imaginada que es la nación, y da las claves para explicar el arraigo de este imaginario, mostrando la interacción entre visualidad y vivencia que actúa en la construcción del paisaje.

Por último, el estudio de los tipos sociales que, como hemos señalado, se abre con los relatos de Tornero, resulta muy interesante porque hace aparecer diferencias y connotaciones: la montaña como un espacio de independencia y de libertad, de un "saber primitivo", donde el arriero se desenvuelve como un sujeto distinto (del inquilino), independiente y emprendedor, respondiendo al ideal progresista $\mathrm{y}$ modernizador de fines del siglo XIX que representa el libro de Tornero. Queda pendiente la tarea de buscar en otros relatos a los personajes que cruzan la frontera junto con los arrieros: los bandidos y cuatreros que, por lo menos en los textos estudiados, permanecen ocultos.

\section{BIBLIOGRAFÍA}

AHUMADA, P. (2003), La cordillère des Andes et Santiago du Chili, le rapport entre représentation, modèles paysager et aménagment du territoire. Memoria de magíster en Jardins, paysages et territoires. Universidad Paris 1.

ANDERMANN, J. (2008), “Paisaje: imagen, entorno, ensamble”, en Orbis Tertius, XIII, 14.

ANDERSON, B. (2000), Comunidades imaginadas, FCE, Buenos Aires.

BERGUER, J. (1972 [2001]), Modos de ver. Barcelona, Gustavo Gili.

BERQUE, A. dir. (1994), Cinc propositions pour une théorie du paysage. Champ Vallon, Paris.

BESSE, J.M. (2009), Le goût du monde. Act Sud, Paris. 
BEVERLY, J. et al. (1995), Manifiesto inaugural. Grupo Latinoamericano de Estudios Subalternos. Duke University.

BURKE, P. (2005), Visto y no visto. El uso de la imagen como documento histórico, Cultura libre, Barcelona.

De CERTEAU, M. (1996), La invención de lo cotidiano. Vol. 1. Artes de hacer. Universidad Iberoamericana, México.

DIENER, P. (2007), “Lo pintoresco como categoría estética en el arte de los viajeros: apuntes para la obra de Rugendas”, en HistoriaI, nº40, Santiago: 285-309.

GAY, C. ([1854] 2004). Atlas de la historia física y política de Chile. Lom Ediciones, Santiago.

GONZÁLEZ Leiva, J. (2007), “Primeros levantamientos cartográficos generales de Chile con base científica: los mapas de Claudio Gay y Amado Pissis”, en Revista Norte Grande, 꿍. Santiago.

HIDALGO, G. (2009), "Panoramic view and national identity: two of Santiago de Chile's public spaces in the second half of the nineteenth century", en Planning Perspectives 24: 3, Routledge, London.

COELHO PRADO, M.L. (2009), “Nación y Pintura Histórica: reflexiones en torno a Pedro Subercaseaux, en A. M. Stuven y M. Pamplona (editores), Estado y nación en Chile y Brasil en el siglo XIX, Ed. Universidad Católica de Chile, Santiago.

LACOSTE, P. (2008), “El arriero y el transporte terrestre en el Cono Sur (Mendoza, 1780-1800)”, en Revista de Indias, vol 68, nº 244, España.

MITCHELL, W.J.T. ed. (1994), Landscape and power. University of Chicago Press. Chicago.

MIZÓN, L. (2001), Claudio Gay y la formación de la identidad cultural chilena. Editorial Universitaria, Santiago.

ORIGO Ediciones (2008), Pintura chilena del siglo XIX. Juan Mauricio Rugendas. La mirada de un viajero, Santiago.

PISSIS, A. (1875). Atlas de la geografía física de la República de Chile. Instituto geográfico de Paris.

PÉREZ de ARCE, R et al. (1993), La montaña mágica. El cerro Santa Lucía y la ciudad de Santiago. Ediciones ARQ, Santiago.

PRATT, M.L. ([1992] 2010), Ojos imperiales. FCE, México. Quijano, A. (2001), “Colonialidad del poder. Cultura y conocimiento en América Latina”, en El Eurocentrismo y la filosofía de la liberación en el debate intelectual contemporáneo, Duke University, Ediciones del Signo, Buenos Aires: 117-132.

ROLLE, C. (2011), “Chile ilustrado por Recaredo Tornero”, en Chile Ilustrado, edición facsímil, Biblioteca fundamentos de la construcción de Chile, Santiago.

RUGENDAS, J.M. ([1838] 1970), Álbum de Trajes Chilenos, en Edición facsímil, Editorial Universitaria, Santiago.

SAGREDO, R. (2009), "Geografía y nación. Claudio Gay y la primera representación cartográfica de Chile”. Estudios Geográficos, Vol. LXX, 266, Madrid.

SAGREDO, R. (2004), "El atlas de Gay y la obsesión por representar Chile", en Atlas de la historia física y política de Chile, edición facsímil, Lom Editores, Santiago.

SCHELL, P. (2003), "Desenterrando el futuro con el pasado en mente. Exhibiciones y museos en Chile a finales del siglo XIX", Relics \& Selves http://www.bbk.ac.uk/ibamuseum/texts/ Schello3sp.htm 
SIMMEL, G. ([1912] 1996), « Philosophie du paysage », en J.P. Le Dantec, comp, Jardins et paysages. Textes essentiels. Larousse, Paris.

TORNERO, S. (1864), Manual de Jeografía. Conforme al programa de la Universidad de Chile y siguiendo el plan de las lecciones de jeografía moderna de D. Jose V. Lastarria. Imprenta el Mercurio, Valparaíso.

TORNERO, R. (1872), Chile ilustrado. Guía descriptivo del territorio de Chile, de las capitales de provincia y de los puertos principales. Librerías i agencias del Mercurio, Valparaíso, Imprenta HispanoAmericana de Rouge, Dunon i Frésné, Paris.

WYLIE, J. (2007), Landscape. Routledge, London. http://www.archivovisual.cl/

\section{NOTAS}

1. Notas: En el marco del Bicentenario se reeditó una edición facsímil, con un excelente artículo de Rafael Sagredo en que estudia el contexto histórico de producción y la difusión que ha alcanzado la obra de Gay.

2. Ignacio Domeyko también llegó a Chile contratado por el gobierno en 1838 para hacer clases en el Liceo de Copiapó, donde formó la escuela de Minas de Copiapó. Participó luego en la formación de la Universidad de Chile de la cual fue rector.

3. El título completo de la obra es Chile ilustrado. Guía descriptivo del territorio de Chile, de las capitales de provincia y de los puertos principales, por Recaredo S. Tornero. Obra adornada con 200 grabados en madera y 10 litografías a dos tintas. Valparaíso. Librerías i agencias del Mercurio. 1872. París. Imprenta Hispano-Americana de Rouge, Dunon i Frésné.

4. Philippi llegó a Chile alrededor de 1850, contratado por el gobierno y es una figura clave del conocimiento de la flora y fauna del país, participó en varias expediciones científicas y en la formación del Museo de Historia Natural.

5. Un álbum de solo cinco láminas que fue el único proyecto editorial que Rugendas publicó en Chile.

6. Originalmente hacienda de los jesuitas, fue comprada por Mateo de Toro y Zambrano, "uno de los más fuertes capitalistas de la época", cuando el Estado confisca los bienes de los jesuitas. Por mayorazgo pasa a sus actuales dueños, Nicolasa Toro de Correa. "La hacienda de la Compañía fue vendida en pública subasta el 28 de octubre de 1771 a D. Mateo de Toro Zambrano, en 90000 pesos, con nueve años de plazo, al cinco por ciento" (Tornero, 1872: 429).

\section{RESÚMENES}

Este trabajo se propone seguir un hilo que va del Atlas de Claudio Gay (1854) a la pintura La Fundación de Santiago (1889), analizando cómo se instala la cordillera nevada como telón de fondo de la nación. Un paisaje nacional que se construye en el siglo XIX, desde la élite republicana, desde Santiago, y que se reproduce hasta hoy. En un segundo plano, usando como referencia los estudios sobre paisaje y poder y paisaje como lugar de vida, el artículo busca indagar en los márgenes de estas representaciones: ¿Existen otras cordilleras (ocultas) del siglo XIX? ¿Cómo se explica el arraigo popular de este imaginario? Relatos sobre de mineros, arrieros o bandidos pueden ser el otro hilo con que se teje el paisaje de la nación. 
Ce travail propose de suivre un fil conducteur, de l'Atlas de Gay (1854) à la peinture La Fondation de Santiago (1889), en analysant comment la cordillère enneigée s'installe comme décor de la nation: un paysage national qui se construit au XIXe siècle, au sein de l'élite républicaine, depuis Santiago, et qui se reproduit encore aujourd'hui. Dans un second temps, en se référant aux études sur le paysage et le pouvoir et au paysage en tant que lieu de vie, l'article cherche à questionner au-delà de ces représentations: Existe-t-il d'autres cordillères (occultes) au XIXe siècle ? Comment explique-t-on l'enracinement populaire de cet imaginaire ? Des récits à propos de mineurs, arrieros (muletiers) ou bandits peuvent-ils être l'autre fil avec lequel se tisse le paysage de la nation.

\section{ÍNDICE}

Mots-clés: paysage national, les Andes, XIXe siècle, muletiers et vachers

Palabras claves: paisaje nacional, los Andes, siglo XIX, arrieros y vaqueanos

\section{AUTOR}

\section{PAULINA AHUMADA F.}

Arquitecta Universidad de Chile. Master en Jardín, paisaje y territorio, Universidad París 1. Doctoranda en estudios americanos, Instituto IDEA, Universidad de Santiago.

ahumada.paula[at]gmail.com 